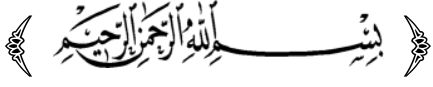

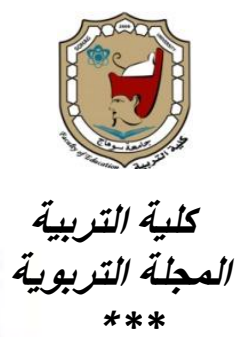

أثر إستراتيجية تدريس قائمة على برنامج قبعات التفكير الست لتنمية مهارات التحلدث ( إدارة الاجتماع ) للدى عينة من طالبات جامعة الحدود الشمالية

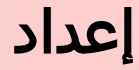 \\ د/ فلك ربيع الخليف
}

عميدة كلية الاقتصاد المنزلى جامعة الحدود الثمالية

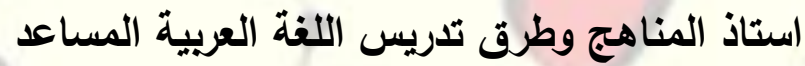

رئيس لجنة مركز القيا س والتقويم مدينة عرعر - المملكة العربية السعودية

$$
\text { المجلة التربوية ـالعدد السابع والخمسون ـيناير 19.rم }
$$

Print:(ISSN 1687-2649) Online:(ISSN 2536-9091) 
|المستخلص

تحددت مشكلة الدراسة في السؤال التالي: ما أثر استخدام إستراتيجية التدريس القائمة على برنامج قبعات التفكير الست لتنمية مهارة التحدث (إدارة الاجتماع) لاى عينة من طالبات جامعة الحدود الثمالية عند تدريسهن مقرر اللغة العربية (1 (r)، وقد استهدفت الاراسة وصف إستراتيجية التدريس القائمة على برنامج قبعات التفكير الست وقياس أثرها في تنمية مهارة التحدث عند إدارة الاجتماعات لاى عينة من طالبات الحدود الثمالية بلغت (Y) طالبة باستخدام المنهج شبه التجريبي فقُسمت العينة إلى عينتين:

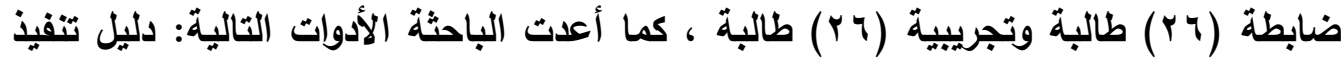
الإستراتيجية القائمة على برنامج قبعات التفكير الست لتريس مقرراللغة العربية (1 ( ب) وقائمة بمهارات إدارة الاجتماع المناسبة لطالبات المرحلة الجامعية ويطاقة ملاحظة لتقويم أداء الطالبات في (إدارة الاجتماع ، ثم طبقت أداة التقويم تطبيقا قبليًا ويعديًا على عينتي الدراسة؛ وقد أثبتت النتائج أثر إستراتيجية التدريس القائمة على برنامج قبعات التفكير الست

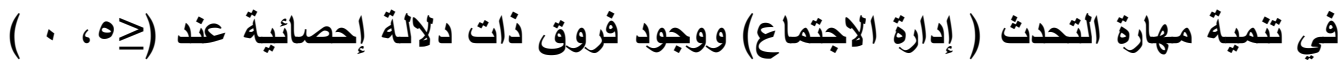
بين متوسطات درجات أفراد العينة التجريبية لصالح الاختبار البعدي وكنللك إعداد قائمنين بمهارات إدارة الاجتماع لرئيس الاجتماع ولأعضاء الاجتماع ووصف إستراتيجية التدريس إنس القائمة على برنامج قبعات التفكير في تتمية مهارة إدارة الاجتماع لاى طالبات المرحلة الجامعية عند تعليم اللغة العربية وتصميم بطاقة تقويم مهارات إدارة الاجتماع. 


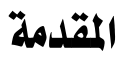

اللغة وسيلة الفرد لقضاء حاجاته والتعبير عن رغباته، وهي وسيلة الأفراد في الاتصال بمجتمعاتهم وسبيلهم لتوحيد كلمتهم فباللغة وحدها يندمج الفرد بمجتمعه ويتلقى كل تراث

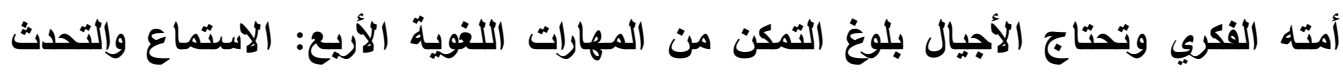
والقراءة والكتابة كي تحافظ على تراثها الفكري .

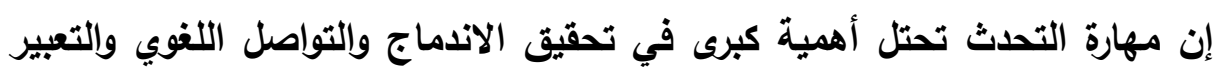

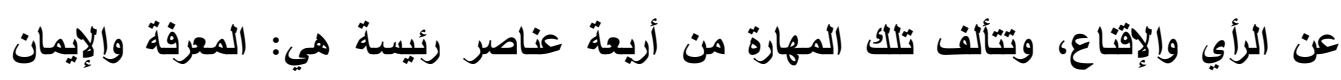

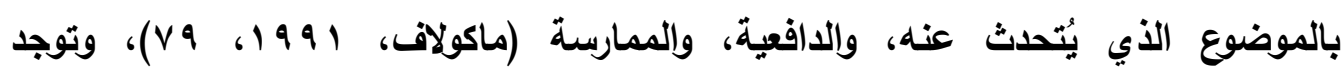

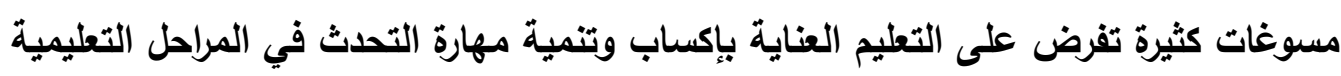

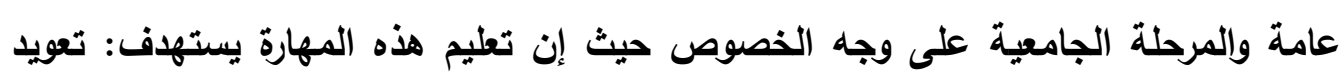

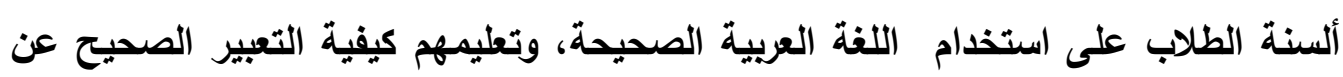

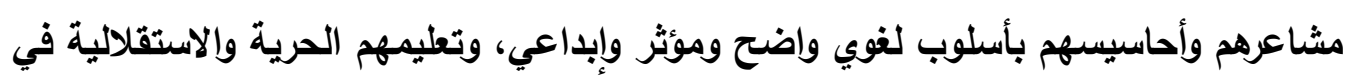

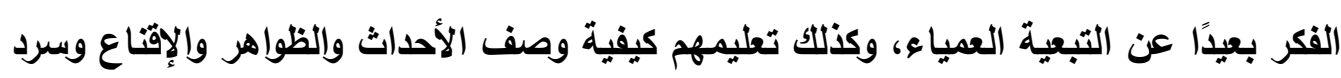

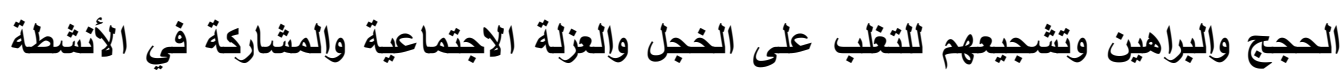

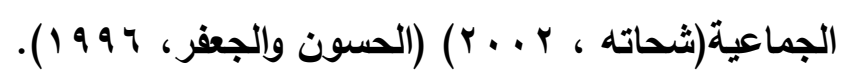

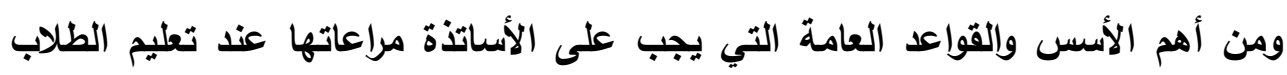

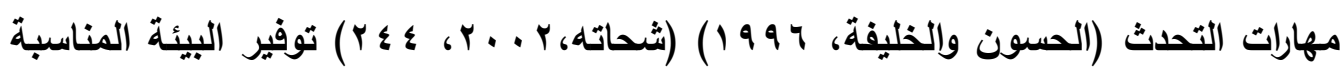

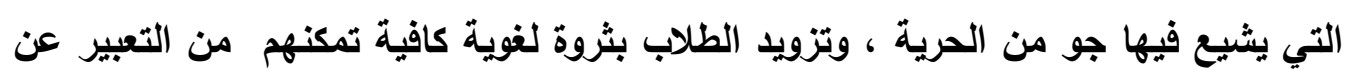

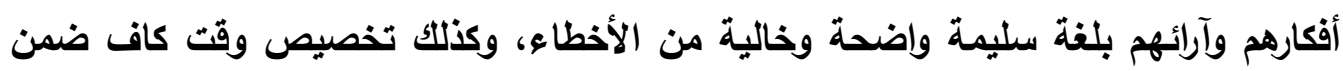

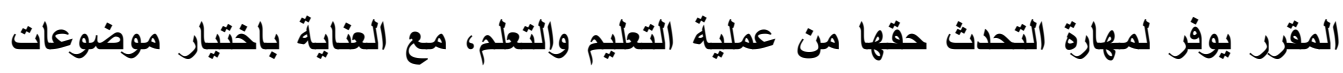

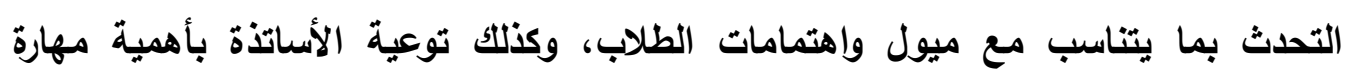
التحلث ودورها في الحياة الاجتماعية ككل وفي العملية التعليمية على وجه الخصوص؛ ولكئ فئن توجد عدة صعويات تعرقل تعليم وتعلم مهارة التحدث بالمرحلة الجامعية تظهر في ثلاث أبعادئ

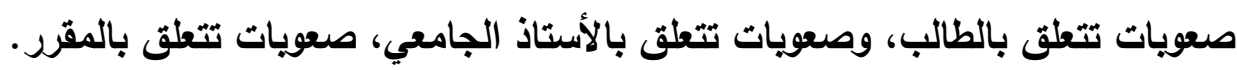

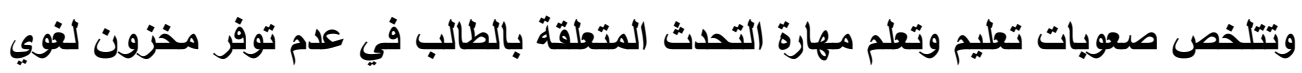

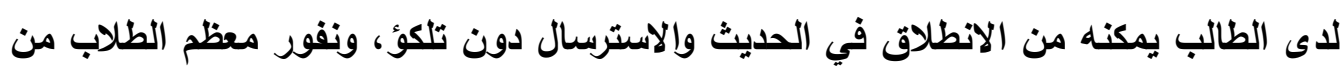


المشاركة في أنشطة المحادثة وذلك لخوفهم من الإخفاق عند التحدث أو بسبب لا مبالاتهم باروس اللغة العربية التي تستهدف تتمية مهارة التحدث كموضوع محضر الاجتماع ونظرتهم بأنه لا فائدة من تعلمها وإنها إضاعة للوقت والجها من وجهة نظرهم، ويعض الصعويات لاى الطلاب تكمن في وجود عيوب صحية أو نفسية أو اجتماعية تعوق بعضهم عن التحدث

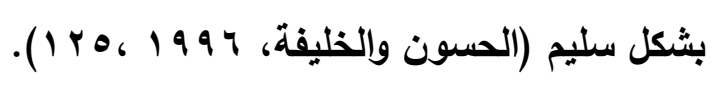

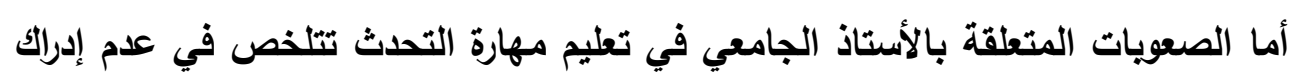

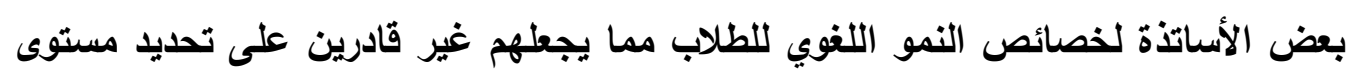
قدرات طلابهم اللغوية، ونظرته إلى مهارة التحدث على أنها نشاط يقاس بالملاحظة العامة وحدها دون اختبارات أو تفصيل للمهارات الفرعية في بطاقات تقويم مقتنة فمعايير تقييم نواتج

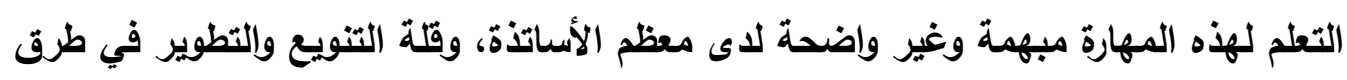
تدريس مهارة التحدث والاعتماد على طرق تدريس اعتيادية، كما أن نظرة بعض الأساتذة

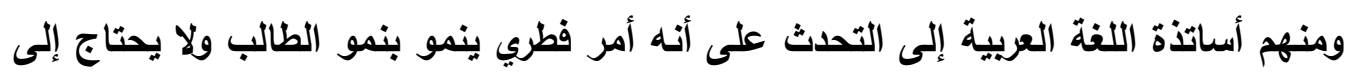
تدريب وتعليم ، وعدم إلمام بعض الأساتذة بمداخل وطرق تدريس وتقويم مهارة التحدث وسبل تنميتها بسبب عدم وجود برامج تدريبية تمكنهم من تدريس مهارة التحدث بأسلوب

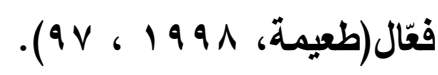
أما الصعويات التي تتعلق بمقررات اللغة العربية في المرحلة الجامعية فقد تم تحديدها بعد إجراء دراسة فاحصة لتوصيفات مقررات اللغة العربية في جامعة الحدود الثمالية ويمكن تلخيصها في: عدم وضوح أهداف تعليم مهارة التحدث مقارنة بأهداف تعليم مهارتي القراعة والكتابة، وافتقار توصيف المقرر لموضوعات تتناسب مع ميول واهتمامات الطلاب الجامعيين

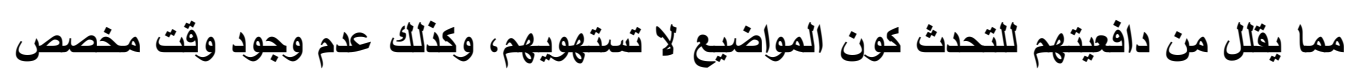

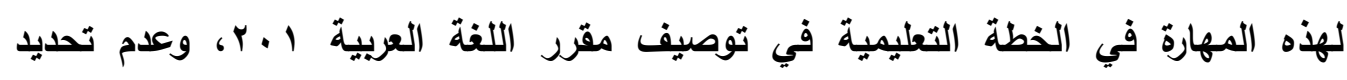
مواصفات واضحة للمتحدث الجيد في ضوء قدرات الطلاب في كل مستوى جامعي، وقلة

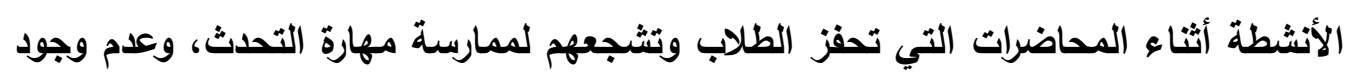

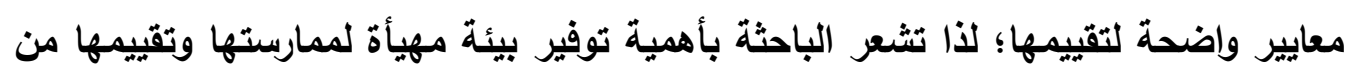
خلال استخدام إستراتيجية تدريسية تتضمن مناشط لغوية تؤدي إلى تمكين طلاب وطالبات المرحلة الجامعية من مهارات التحدث. 
ووزارة التعليم بالمملكة العربية السعودية لم تأل جهدًا في العناية بتعليم اللغة العربية لطلاب المرحلة الجامعية فوفرت الأقسام المخصصة لتعليم اللغة العربية لكافة كليات الجامعة ، وجعلت مادة اللغة العربية ضمن المواد الإجبارية لا يتخرج الطالب إلا بعد أن يحقق درجة الجهابه

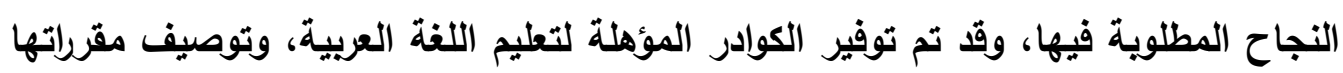
حفاظًا على اللغة التي تمثل الهوية. ولكن مازالت الممارسة اللغوية دون المستوى المأمول وقد تجلى ذلك في نتائج الطالبات

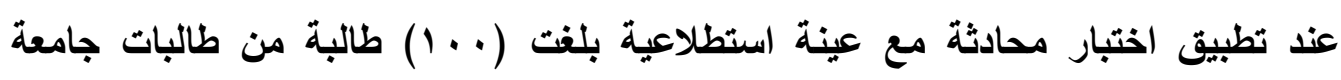
الحدود الثمالية بهدف تحديد مستوى تمكنهم من مهارة التحدث في الانطلاق والضبط اللغوي وشرح الفكرة وترابط الأفكار؛ وكانت النتائج كالتالي:

\begin{tabular}{|c|c|c|c|c|c|}
\hline \multicolumn{5}{|c|}{ مستوى الطالبات } & \multirow[b]{2}{*}{ مهار ات التحدث } \\
\hline غرض & مقبول & جيد & جدًا & ممتاز & \\
\hline$\mu$ & TV & TY & 10 & $r$ & الانطلاق \\
\hline rᄉ & rᄉ & IT & 1. & $r$ & الضبط اللغوي \\
\hline rq & YI & $r$. & IT & $\Lambda$ & شر ح الفكرة الرئبسة \\
\hline$\varepsilon$. & $r$. & 19 & 17 & 0 & تر ابط الأفكار \\
\hline
\end{tabular}

إن تلك النتيجة المتدنية كشفت عن قصور مهارات التحدث لاى طالبات العينة

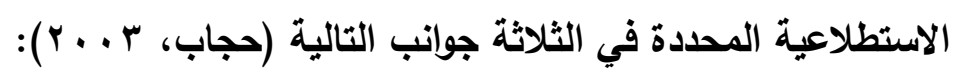
أولا- مهارات المتحدث الشخصية: الموضوعية، وهي حيادية المتحدث. والصدق، وهو أن يعبّر المتحدث عنما يشعر به فيكون حديثه أكثر تأثيرًا في مستمعيه. والوضوح، ومعناه أن يتحدث المتحدث بطريقة غير معقدة ليكون كلامه عميق التأثير في نفوس المستمعين. والدقة ، وهي استخدام المتحدث كلمات تعبر عن المعنى المقصود دون التباس. والحماس، ومعناه تفاعل المتحدث مع مستمعيه من خلال نبرة الصوت وحركة الجسد، والخلفية المعرفية حول الموضوع فلا يكون الورق ملازمًا له طوال فترة حديثه. 
ثانيًا - مهارات المتحدث الصوتية، ومنها: الاهتمام بنظق الحروف نطقًا صحيحًا وضبط الكلمات، ووضوح الصوت ومناسبة درجته عدد الحضور، وتنويع سرعة ويطء الحديث حسب الامباء أهمية ما يتحدث عنه فيسرع بالحديث عند نقاط معينة ويبطئ في نقاط أخرى، وحُسن الوقفات في الحديث سواء كانت وقفات ناقصة في منتصف الحديث أم وقفات قاطعة في نهايته. ثالثًا - مهارات الإقناع ومنها: مهارة عرض الموضوع بطلاقة وسلاسة، وتقبل النقد، وتحليل بعض النقاط وابتكار جمل ومعانٍ جديدة تبهر المستمعين، ومهارة ضبط نفسه وإنفعالاته عند تفاعله مع المستمعين. إن ذلك القصور في مهارة التحدث لاى العينة الاستطلاعية دفع الباحثة نحو محاولة علمية جادة لتحديث إجراءات التدريس وأساليب التقويم المتبعة في تدريس مقررات اللغة العربية ؛ واستخدام إستراتيجية تدريس قائمة على برنامج قبعات التفكير الست، لتنمية مهارة

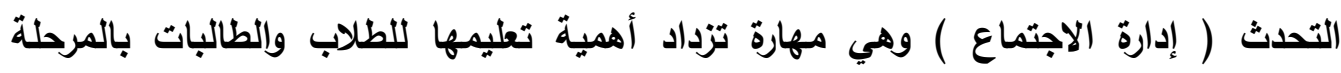
الجامعية لحاجتهم إلى عقد الاجتماعات لاتخاذ قرارات مهمة لمشاريعهم الجامعية ولغيرها من الأغراض الجامعه

\section{مشكالة الداراسة}

يعدّالارتباك والتوتر مشكلة رئيسة عند التحدث وممارسة التفكير أثناء الاجتماعات ،فيفي لحظة التفكير يقوم المتعلم بأكثر من نمط تفكير في آن واحد فهو يستدعي المعلومات

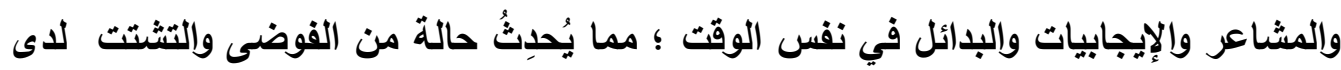
المتحدث تنعكس سلبا على قراراته والتخبط في إيجاد حلول لمشكلاته، بينما نجد أن برنامج

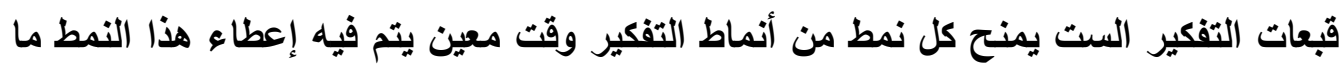
يستحقه من تفكير ونقاش دون تثتت وارتباك (Curran,2003,36)؛ ويتطلب تدريب طلاب

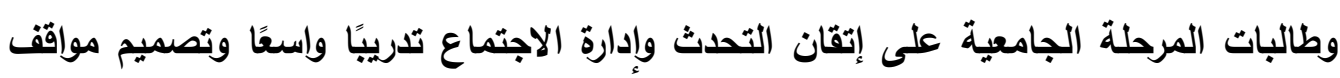
تدريسية من خلال تعليم مقررات اللغة العربية بالمرحلة الجامعية باستراتيجيات حديثة تعتمد

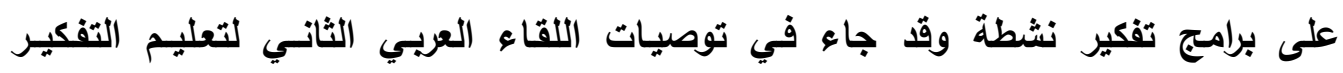

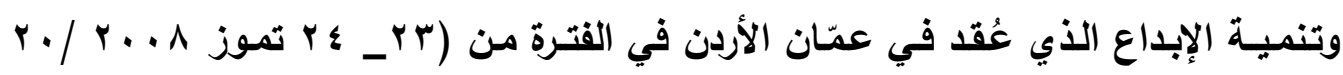

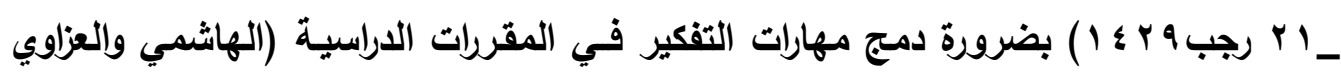


كما ظهرت في الآونة الأخيرة برامج تسعى لتنمية مهارات التفكير منها: برنامج (Y. . V،

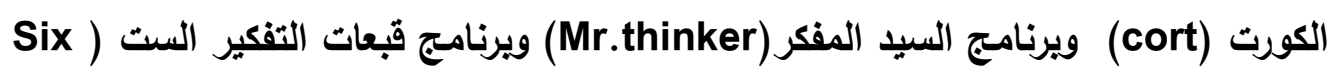
(thinking hats وهو أحد البرامج التي أثبتت نجاحها وفاعليتها في تعليم إدارة الاجتماعات وبرنامعات وذلك بحسب ما أثشار إليه مبتكره إدوارد دي بونو(Edward De Bono,2001.46 ) بقوله: " إنك تستطيع أن تدير أي اجتماع أو نقاش باستخدام وارتداء القبعات وما ترمز إليه بسهولة ويسر" ويهدف هذا البرنامج إلى تنمية التفكير وتحويل المواقف الجامدة والسلبية إلى إنى مواقف إبداعية باستخدام ست قبعات افتراضية ملونة ترمز كل قبعة إلى نوع معين من إنى

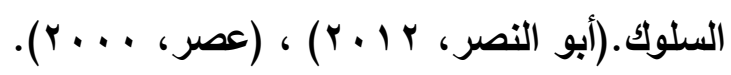

وعلى _ حد علم الباحثة _ لا توجد دراسة سابقة استخدمت برنامج قبعات التفكير الست

لتنمية مهارة التحدث في إدارة الاجتماع عند تعليم اللفة العربية طلاب المرحلة الجامعية. وعلى الرغم من أهمية مهارة التحدث ومهارة إدرة الاجتماع في المرحلة الجامعية إلّا أن

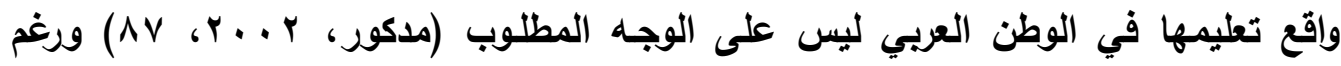
أهمية تلك المهارة فإن الأساتذة ليس لايهم فكرة عن الإستراتيجيات والطرق والأساليب

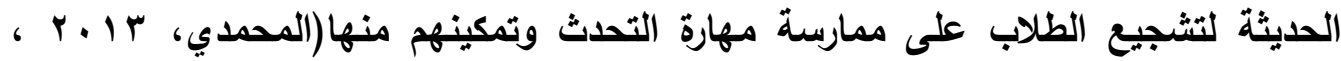

وقد أشار استطلاع الواقع التربوي الجامعي بجامعة الحدود الثمالية عند تعليم مهارة

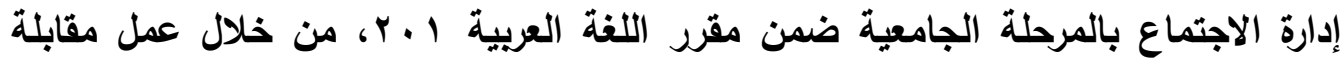
شخصية مع عدد أستاذات اللغة العربية بالمرحلة الجامعية(ملحق ا)؛ لمعرفة إستراتيجيات تدريس مهارة التحدث في موضوع محضر الاجتماع تبين أن هناك قصورًا في آلية تدريسها حيث يتم الاعتماد على مشاهدة اجتماع مسجل (من اختيار الأستاذة عبر جهاز العرض المرئي أو شاشة العرض الرقمية ، ومن ثم تدوين أهم خطوات ومراحل سير هذا الاجتماع من اهن قبل الطالبات، ثم محاكاة ذلك بعقد اجتماع داخل الصف بنفس خطوات ومراحل الاجتماع المعروض مسبقًا، إضافة إلى عدم وجود معاييز واضحة لتقويم مهارة إدارة الاجتماع فلا توجد بطاقة تقويم خاصة لكل مهارة من مهارات التحدث الفرعية وما يتفرع عنها من مهارات فرعية أخرى؛ لذا فإن التعليم الجامعي ينبغي أن يتجه إلى تعليم الطلاب والطالبات سبل إدارة الاجتماع، وأدوار الأعضاء فيه و القائمين عليه في مواقف تعليمية نشطة باستخدام برامج لئه 
تعليم سهلة مع الاهتمام ببعض المهارات التي ينبغي تعليمها للطلاب بشكل مبسط (شحاتة، $\cdot(r . . r$

ويناء على ما سبق تتلخص مشكلة الدراسة في عدم وجود إستراتيجية واضحة الإجراءات يمكن أن يستخدمها الأستاذ الجامعي لتتمية مهارة التحدث أثناء إدارة الاجتماعات

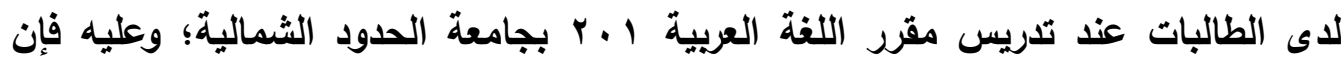
الحاجة قائمة لوصف إستراتيجية تدريسية ومعرفة أثرها لتتمية مهارات التحدث أثثاء إدارة الاجتماعات لاى عينة من طالبات جامعة الحدود الشمالية بالمملكة العربية السعودية . و تتطلب مشكلة البحث الاجابة عن السؤال الرئيس التالي: ما أثر إستراتيجية التدريس القائمة على برنامج قبعات التفكير الست لتنمية مهارة إدارة الاجتماع لاى طالبات جامعة الحدود الشمالية عند دراسة مقرر اللغة العربية؟ ويتفرع منه الأسئلة الفرعية التالية: س ا - ما قائمة مهارات إدارة الاجتماع لروئساء الاجتماع ولأعضاء الاجتماع اللازم تنميتها لاى الطالبات عند دراسة مقرر اللغة العربية؟ سץ - ما خطوات إستراتيجية التدريس القائمة على برنامج قبعات التفكير الست أثناء تدريس مقرر اللغة العربية ؟ فروض اللدراسة ؛ للإجابة عن تساؤلات الدراسة وضعت الباحثة الفروض التالية: - توجد فروق ذات دلالة إحصائية ( عند مستوى الدلالة ه>ه . . . بين متوسطي درجات عينة الطالبات بجامعة الحدود الشمالية في بطاقة تقويم مهارة العرض والتقديم في المجموعتين التجريبية والضابطة لصالح المجموعة التجريبية. - توجد فروق ذات دلالة إحصائية ( عند مستوى الدلالة ه>ه ه. . ) بين متوسطي درجات عينة الطالبات بجامعة الحدود الشمالية في بطاقة تقويم مهارة الموضوعية في الطرح في المجموعتين التجريبية والضابطة لصالح المجموعة التجريبية . - توجد فروق ذات دلالة إحصائية (عند مستوى الدلالة ه>ه ه. . ) بين متوسطي درجات الطالبات بجامعة الحدود الشمالية في بطاقة تقويم مهارة التعبير عن المشاعر في ماتي المجموعتين التجريبية والضابطة لصالح المجموعة التجريبية . 
- توجد فروق ذات دلالة إحصائية (عند مستوى الدلالة ه>ه .. .) بين متوسطي درجات

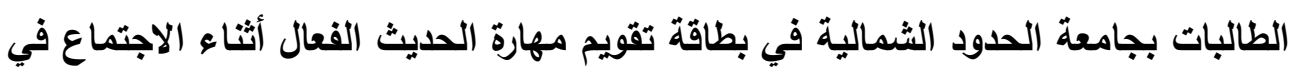

المجموعتين التجريبية والضابطة لصالح المجموعة التجريبية .

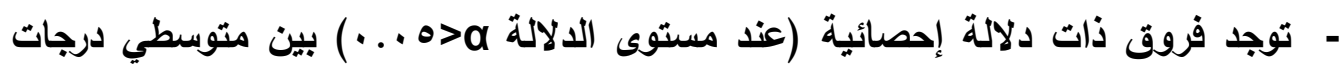
طالبات المرحلة الجامعية في بطاقة تقويم مهارة نقا موضوع الاجتماع في المجموعتين التجريبية والضابطة لصالح المجموعة التجريبية .

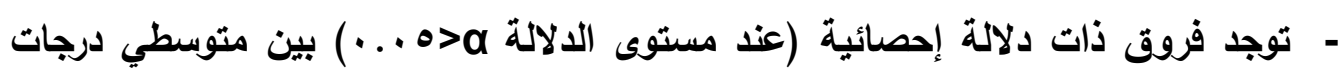
الطالبات بجامعة الحدود الثمالية في بطاقة تقويم مهارة إثراء موضوع الاجتماع فكريًا في دائه المجموعتين التجريبية والضابطة لصالح المجموعة التجريبية. - توجد فروق ذات دلالة إحصائية (عند مستوى الدلالة ه>ه . . . بين متوسطي درجاته

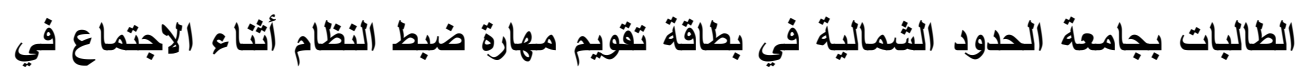
المجموعتين التجريبية والضابطة لصالح المجموعة التجريبية .

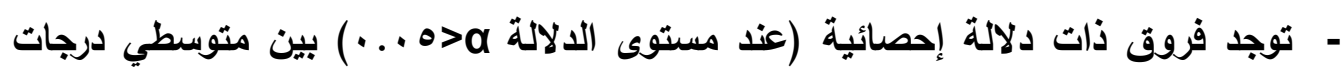
الطالبات بجامعة الحدود الشمالية في بطاقة تقويم مهارة حسن ختام الاجتماع في المجموعتين التجريبية والضابطة لصالح المجموعة التجريبية .

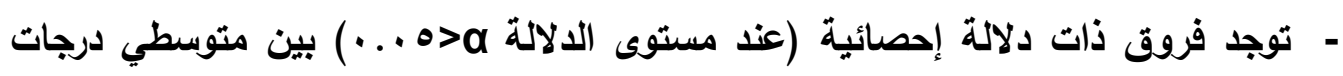

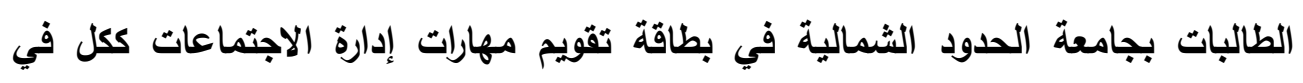
المجموعتين التجريبية والضابطة لصالح المجموعة التجريبية.

أهداف الدراسة هدفت الدراسة الحالية إلى: مانى - قياس أثر إستراتيجية التدريس القائمة على برنامج قبعات التفكير الست لتنمية مهارة إدارة الاجتماع لاى عينة من طالبات جامعة الحدود الشمالية عند دراسة مقرر اللغة العربية.

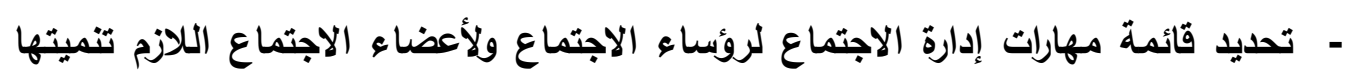
لدى الطالبات عند دراسة مقرر اللغة العربية. 
- بناء خطوات إستراتيجية التدريس القائمة على برنامج قبعات التفكير الست أثناء تدريس مقرر اللغة العربية .

\section{رابعًا - أهمية الدراسة:}

تأتي أهمية هذه الاراسة في النواحي التالية:

- إن تدريب طلاب وطالبات المرحلة الجامعية على مهارة التحدث وإدارة الاجتماع يعطي دلالة واضحة على تحضر المجتمع وتطوره وشيوع ممارستها في المجتمع الجامعي لله

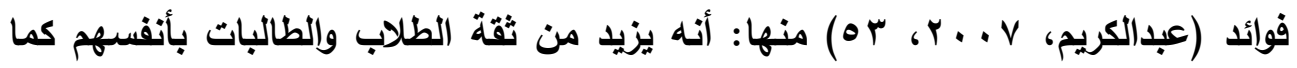
تزيد من ثقته وولائهم للجامعة التي يدرسون فيها وتجعهم يجدون التقدير والاحترام

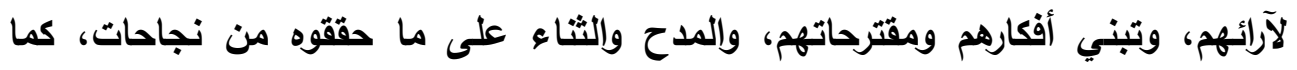
يجدون في المقابل النقد الهادف لأخطائهم مما يسهم في التعديل والتطوير لمخرجات الجامعة التي يدرسون فيها ، كما أن الاجتماعات وسيلة تعليمية وتثقيفية ذلك من خلال

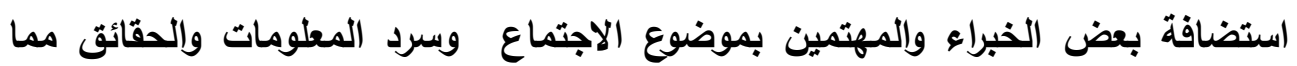

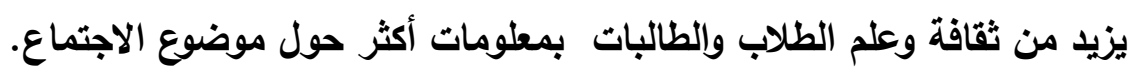

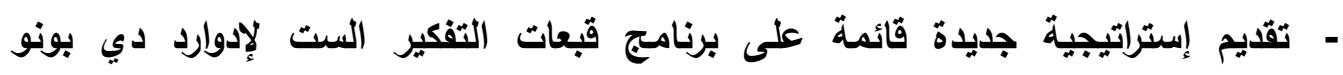
لتدريب الأساتذة الجامعيين على آلية تدريس مهارة إدارة (Edward De Bono) الاجتماع؛ لتمكين الطالب منه بأسلوب علمي وكذلك عند تدريس مقررات جامعية أخرى لتنمية متغيرات بحثية أخرى مثل: مهارات تفكير أخرى كالتفكير الناقد والإبداعي.

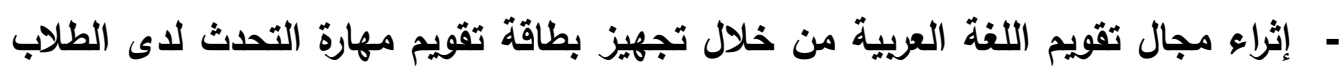
عند إدارة الاجتماع أثناء تعليم مقرر اللغة العربية. - إن إستراتيجية التدريس القائمة على برنامج قبعات التفكير الست تساعد طلاب وطالبات

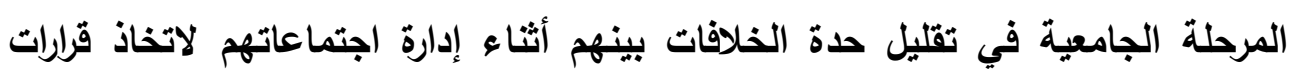
مهمة بخصوص المشاريع الجامعية لأن برنامج قبعات التفكير الست يسعى لتحقيق التفكير المتوازي بين المجتمعين. 
مصطاحات اللدراسة

تضمنت هذه الدراسة المصطلحات التالية: ا. إستراتيجية التدريس القائمة على برنامج قبعات التفكير الست

Strategy إستراتيجية

إستراتيجية: مصطلح إنجليزي ليس لله مرادف في اللغة العربية (بدوي، د ت ،

اصطلاحًا: إستراتيجية التدريس عبارة عن "مجموعة من إجراءات التدريس المختارة سلفًا من

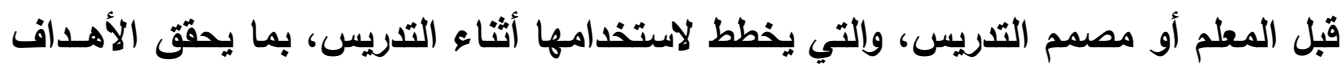

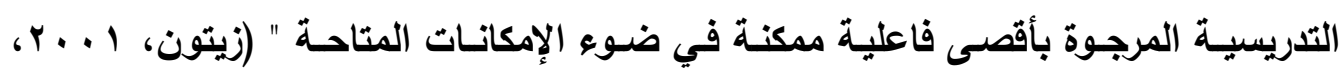
.$(r \wedge)$

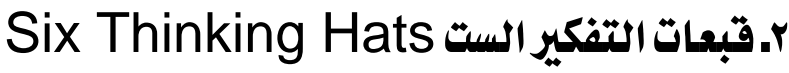

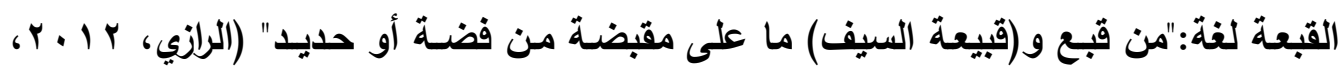

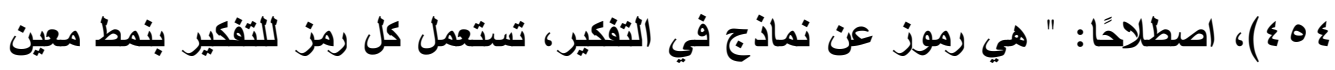

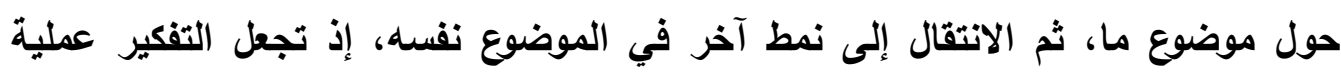
منظمة منضبطة " (EdwardDeBono,2001,16). وتعرّف الباحثة (إستراتيجية التدريس القائمة على برنامج قبعات التفكير الست) إجرائيًا بأنها: مجموعة من الخطوات الإجرائية يقوم بها الأستاذ وفق طبيعة نمط التفكير التي تستثيره كل بلهيل قبعة، ويتم استخدامها بمشاركة عدد من الطالبات وكل قبعة تمارس فيها الطالبات نمطًا معينًا من التفكير يلتزم بها مدير وأعضاء الاجتماع بهدف حل مشكلة أو اتخاذ قرار.

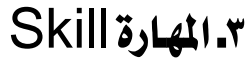

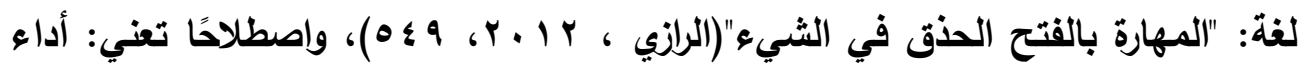
لغوي يتميز بالسرعة والدقة والكفاعة والفهم، مع مراعاة القواعد اللغوية المنطوقة والمكتوبة المية (عليان ، 1991) التعريف الإجرائي: هي قدرة الطالبة الجامعية على ممارسة نمط التفكير الذي ترمز إليه كل قبعة تفكير بأقصى كفاية ممكنة أثناء الاجتماع. 
Speaking عـ التحدث

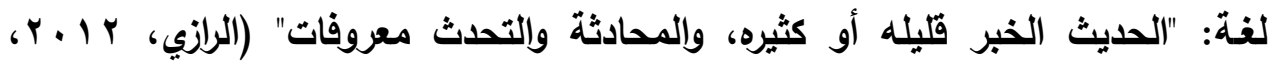

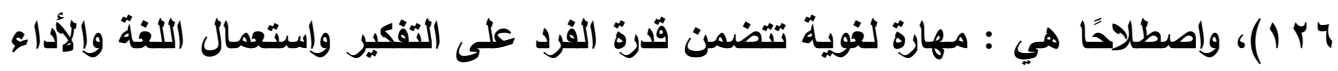
الصوتي والحركي في التعبير الثفوي عن المشاعر والأفكار والمواقف والأغراض ونقاهيا للآخرين بطريقة وظيفية أو إبداعية ويتطلب التمكن من مهارات مدددة لتحقيق الهدف

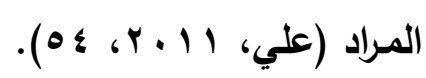

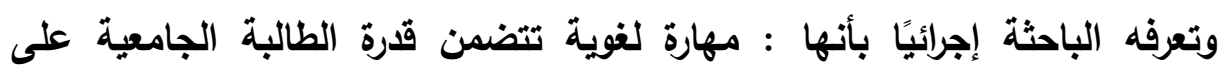

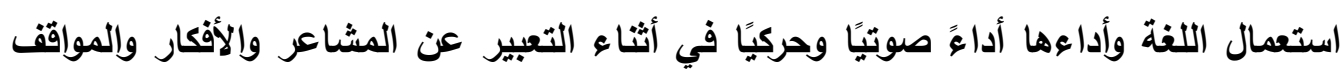

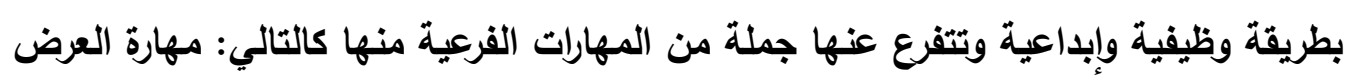

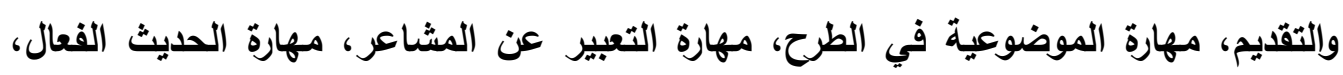

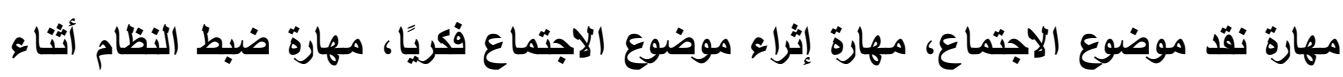
الاجتماع، مهارة حسن ختام الاجتماع.

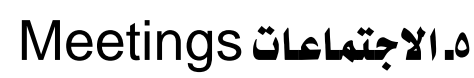

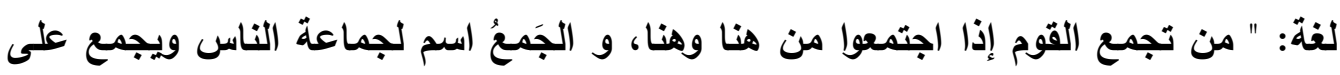

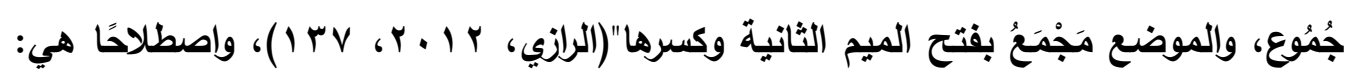

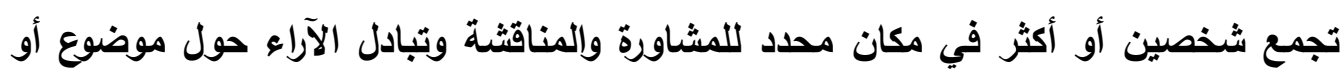

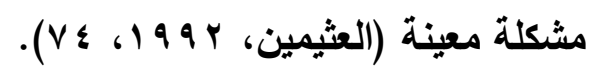
وتعرفها الباحثة إجرائيًا بأنها: مهارة فرعية من مهارات التحدث الواردة في مقرر اللغة

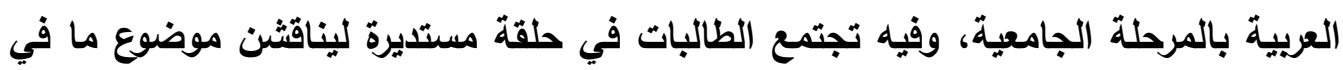
ضوء قبعات التفكير الست، بغية إتقان المهارات الفرعية لمهارة إدارة الاجتماعات، ومنها:

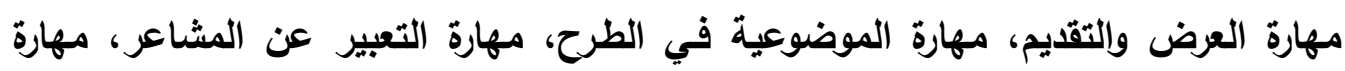

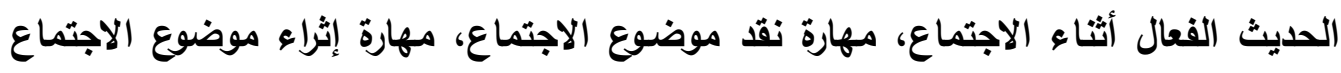
فكريًا، مهارة ضبط النظام أثناء إدارة الاجتماع، مهارة حسن ختام الاجتماع. 
حلدود الدراسة

اقتصرت الاراسة الحالية على:

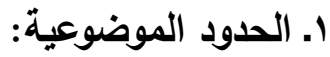

مهارات إدارة الاجتماع الفرعية وهي إحدى مهارات التحدث وتتضمن تدريب الطالبات على

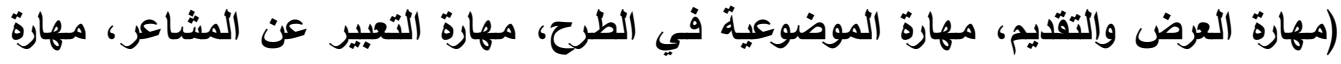

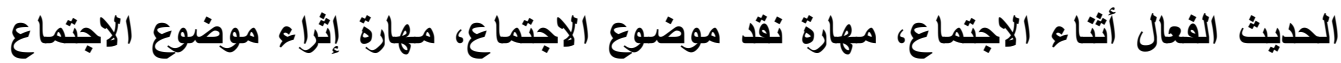

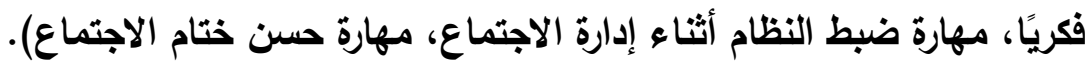
برنامج قبعات التفكير الست وأنماط تفكير القبعات الست.

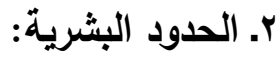

عينة مكونة من rه طالبة من الطالبات الارسات مقرر اللغة العربية ل ـr.

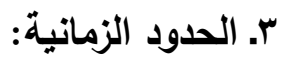

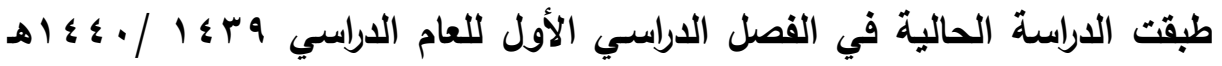

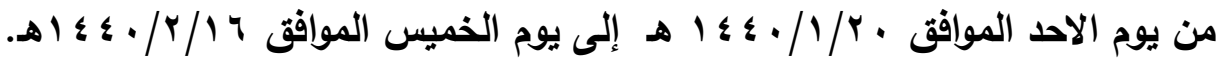
الإطار النظري يعرض الإطار النظري نبذة عن إدارة الاجتماعات ويرنامج قبعات التفكير الست مما له

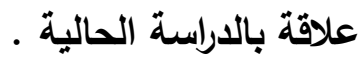
إدارة الاجتماعات تعدّ إدارة الاجتماعات من أهم وسائل الاتصال اللغوي الجماعي الهادف والمخطط حيث

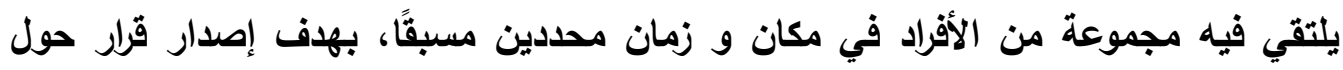

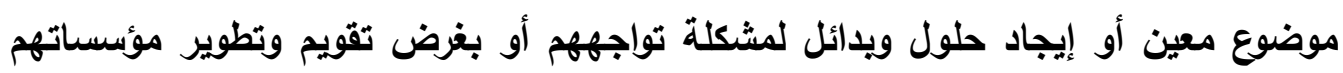

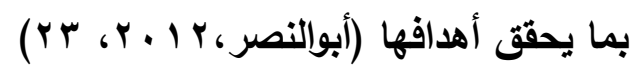

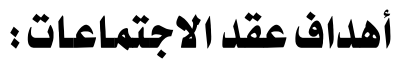
يتم عقد الاجتماعات لتحقيق عدد من الأهداف المختلفة باختلاف توجهات المؤسسات

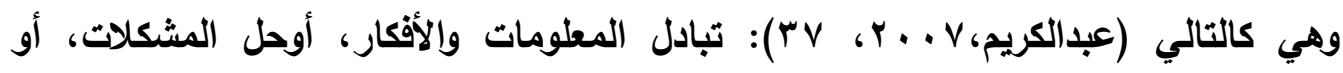

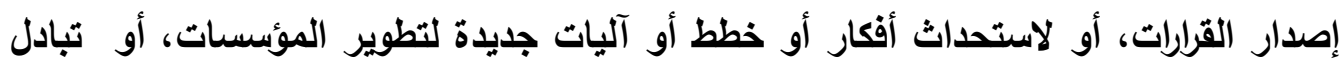


الخبرات والأفكار ووجهات النظر بين أعضاء الاجتماع داخل المؤسسة وخارجها، أو للفصل في المنازعات، أو لوضع الخطط ، أو لمتابعة تنفيذ الأعمال والخطط ، وتطوير وتقييم أعمال

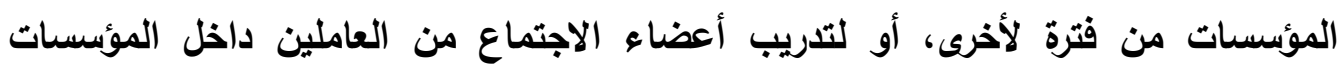
وتشجيعهم لصقل مواهبهم وزيادة إمكانياتهم السلوكية والمعرفية، ولتوزيع المهام والمسؤوليات على العاملين قبل البدء بخطط التتفيذ.

عناصر الاجتماع:

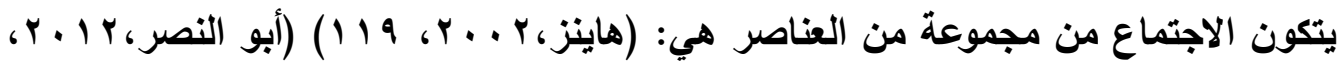

عناصر بشرية: وهم المشاركون في الاجتماع. عناصر مادية: تجهيزات وإعدادات الاجتماع.

موضوع الاجتماع: ويتضمن عادة مجموعة متعددة من الأفكار التي يهدف المشاركون إلى مناقشتها وإتخاذ قرارات بشأنها. التفاعل: هو إيجابية المشاركين وحيويتهم في الطرح وتفاعلهم أثناء الاجتماع.

مراحل إدارة الاجتماع: تمر إدارة الاجتماع بثلاث مراحل متتالية ومرتبطة ببعضها البعض حيث تكمل كل مرحلة

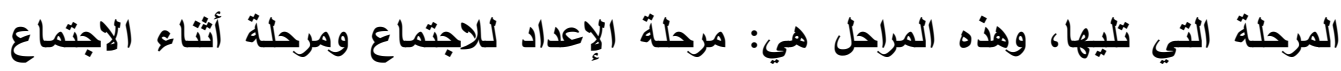

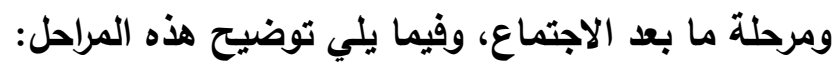
المرحلة الأولى - مرحلة الإعداد ليلاجتماع: وهي مرحلة التحضير والتهيئة للاجتماع، ويقصد بها الجها المبذول لتحضير الاجتماع قبل حضور الأعضاء لقاعة الاجتماعات، وفي هذه المرحلة يتم تحديد الأهداف، وجمع المعلومات وتحديد الزمان والمكان لعقد الاجتماع، وإرسال الدعوة إلى الأعضاء للحضور

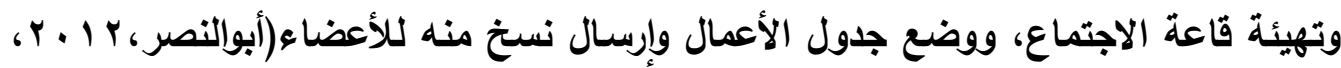

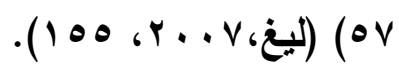




\section{المرحلة الثانية - مرحلة أثناء الاجتماع:}

يعتمد نجاح هذه المرحلة على نجاح المرحلة السابقة وتبدأ بلحظة افتتاح الاجتماع،

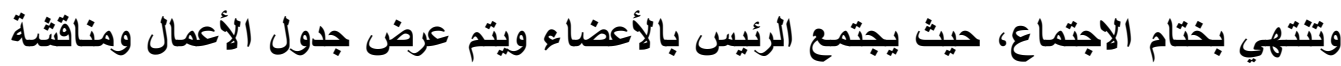

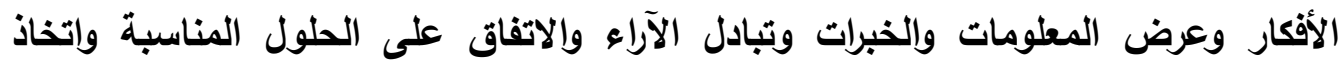

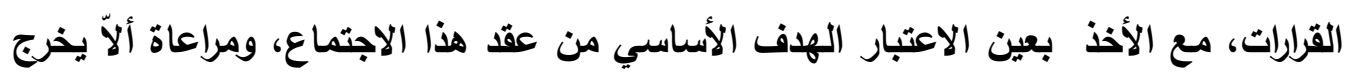
النقاش عن موضوع الاجتماع والالتزام بالوقت المحدد، والدفاظ على الاحترام بين الرئيس

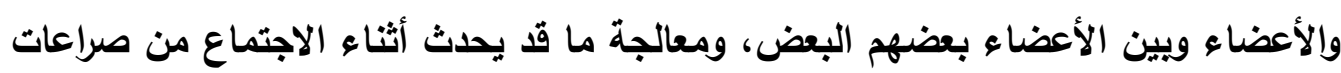

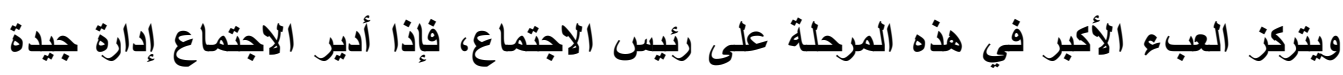

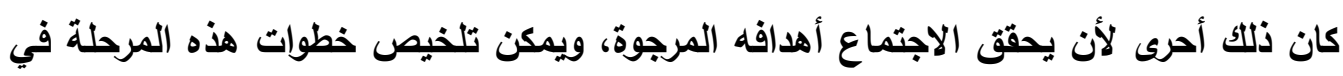

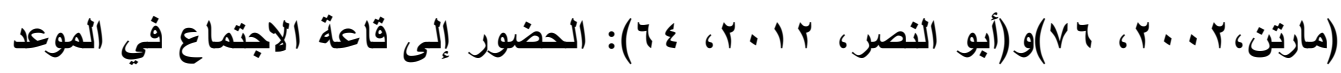

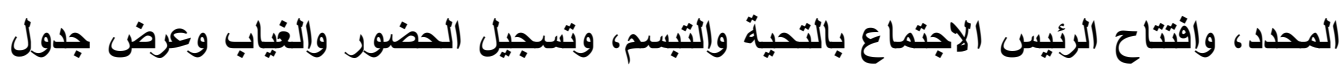

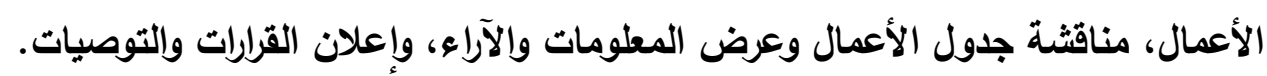
المرحلة الثالثة - ما بعد الاجتماع: مئل تسمى هذه المرحلة مرحلة تقويم الاجتماع، وفيها يتم تحديد نقاط القوة والإيجابيات في

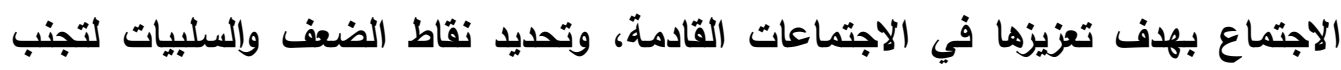

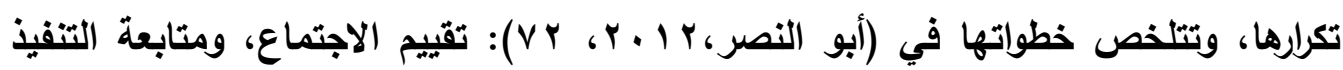

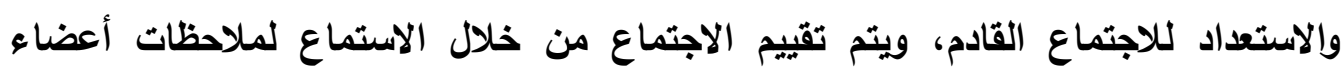

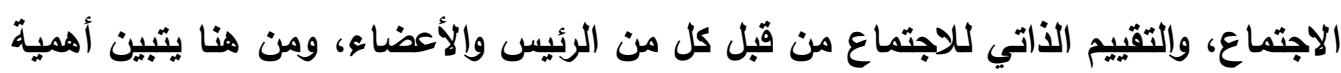

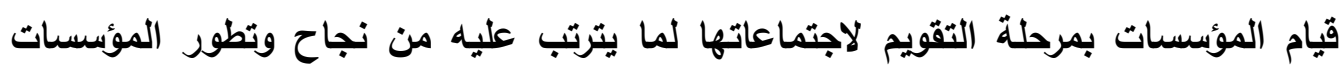

والأفراد. - إن.

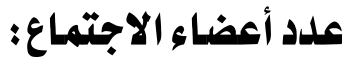

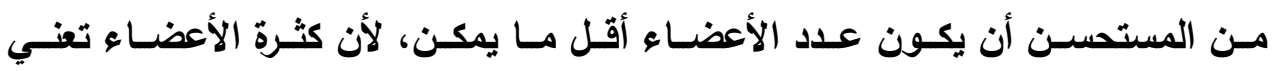

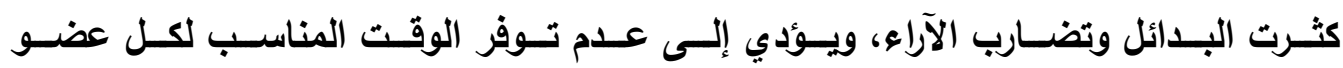

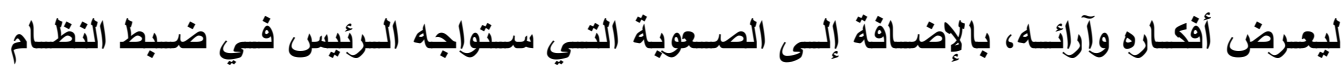

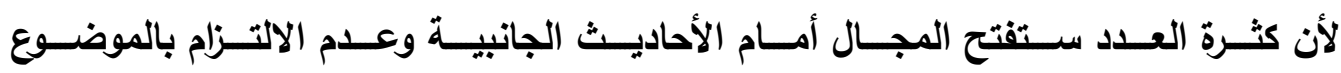




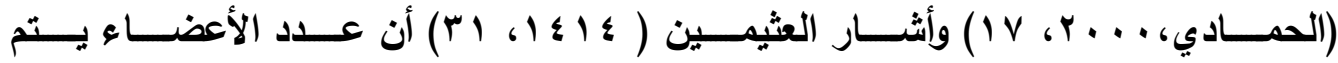
تحديـده بنـاء على هـدف الاجتمـاع، فـإذا كـان هـدف الاجتمـاع تبـادل الآراء والأفكـار فـلا

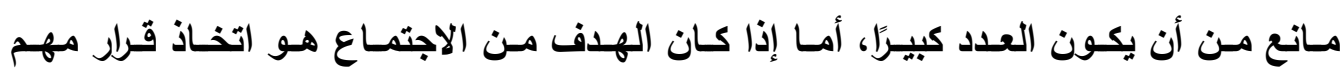
فينبخي تقليل العدد بحيث يتراوح ما بين خمسة إلى سبعة أثخاص. 0. فريق عمل الاجتماع: تتكون غالبية الاجتماعات من: رئيس الاجتماع وأعضاء الاجتماع، وفيما يلي تفصيل مهام

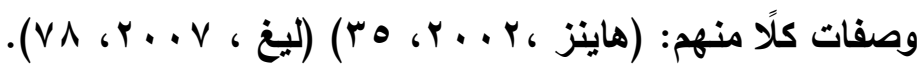

$$
\begin{aligned}
& \text { أ. رئيس الاجتماع: تتلخص مهامه فيما يلي: }
\end{aligned}
$$

تحديد أهداف الاجتماع المتوقع تحقيقها، ووضع بنود جدول أعمال الاجتماع، وإختيار

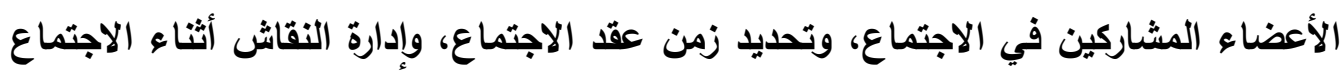

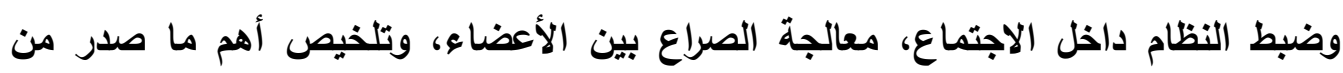

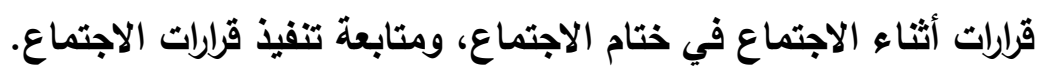
بـ أعضاء الاجتماع: من أبرز صفات العضو الناجح في الاجتماع:

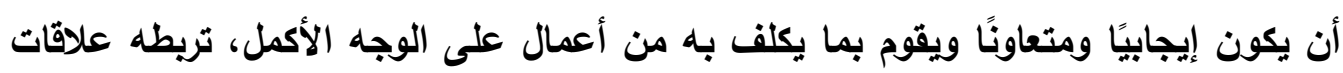
اجتماعية جيدة مع الرئيس ومع بقية الأعضاء، والالتزام بمواعيد الاجتماع ويكون مستمعًا

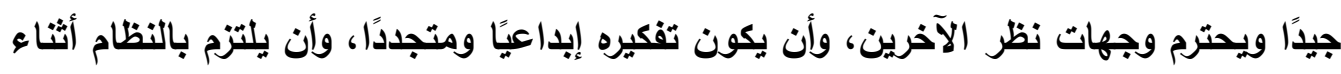
الاجتماع ويحافظ على الههوء. قبعات التقكير الست من أوائل الرواد الداعين واللداعمين لتعليم مهارات التفكير ودمجها في المقررات الدراسية العالم البريطاني إدوارد دي بونو صاحب أشهر برامج تعليم التفكير مثل برنامج الكورت CORT ويرنامج قبعات التفكير الست Six Thinking Hat وهو محور هذا لبون لبحث وسنتطرق لله فيما يالي: برنامج قبعات التفكير الست: هو أحد برامج تتمية مهارات التفكير، و تكمن قيمته التريوية في سهولة استخدامه وملائمته لمواقف الحياة المختلفة، فهو يوجه الفرد إلى أن يفكر بطريقة معينة ثم ينتقل به به بهابه 
إلى التفكير بطريقة أخرى، مما يجعله ينظر نظرة شاملة للموضوع ويالتالي يصدر قرارًا أو حلًا

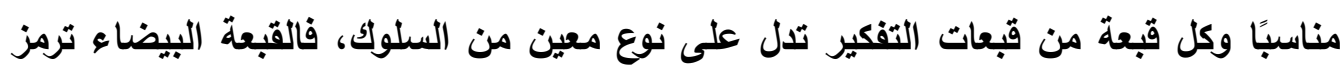

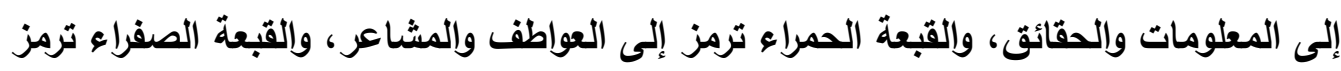
إلى الايجابيات والفوائد، والقبعة السوداء ترمز إلى السلبيات والنقد، والقبعة الفيعة الخضراء ترمز

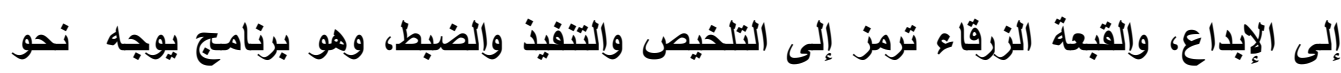

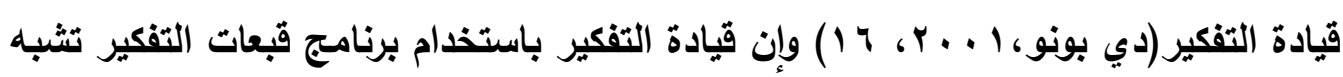
قيادة قائد الفرقة الموسيقية لفرقته فهو" ينتقل بهم إلى مسارات مختلفة رغم اختلاف أداءهم

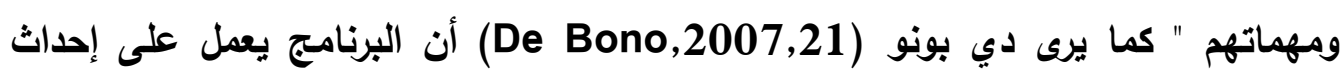
تغييرات في الأداء وتعديل في السلوك وتحسين الحوار، وعرض الأفكار ومشاركة الجميع في بوني انتاجها وتبادلها بدلًا من التعصب لوجهة نظر واحدة، مما يكون له الأثر في تحويل البيئة

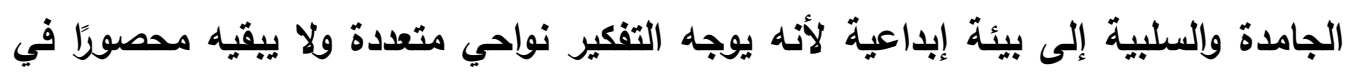
جاتب واحد، ويذلك يتعلم الطالب كيف يعمل عقله وتفكيره في مواقف حياته ككل، حيث يمكنه

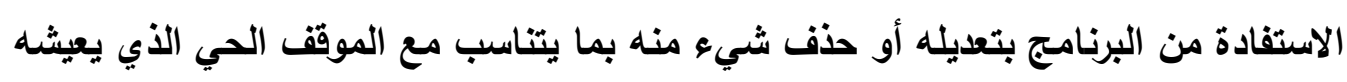

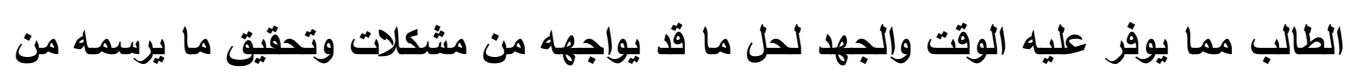

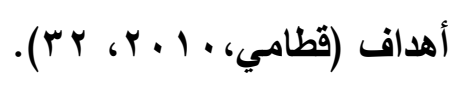

\section{وفيما يلي عرض لقبعات التفكير الست ومدلولاتها بشيء من التفصيل:}

- قبعة التفكير البيضاء: ترمز هذه القبعة إلى الصفاء والنقاء، وهو ما يشير إليه نمط

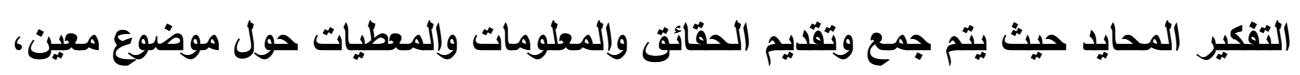
دون الالتفات إلى ما يتعلق بهذا الموضوع من مشاعر وإيجابيات وسلبيات مثل جمع

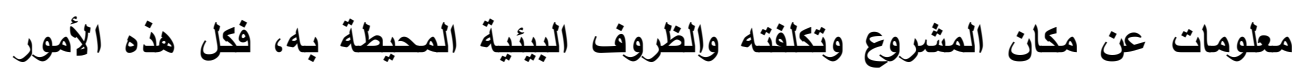

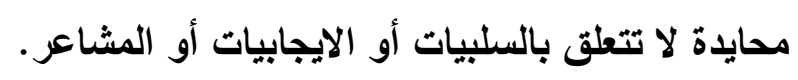

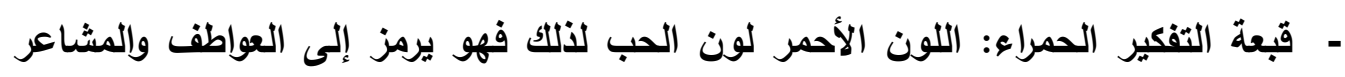
والأحاسيس المتعلقة بالموضوع، فحين نرتدي هذه القبعة نفكر في الموضوع من منظور عاطفي بغض النظر عن المنطق والايجابيات والسلبيات حول هذا الموضوع، ومدتها قصيرة لا تتجاوز · ب ثانية للتعبير عن ما نشعر به تجاه فكره أو قرار أو موضوع معين. 
- قبعة التفكير الصفراء: ترمز في لونها إلى الثمس، والثمس رمز للتفاؤل والإيجابية

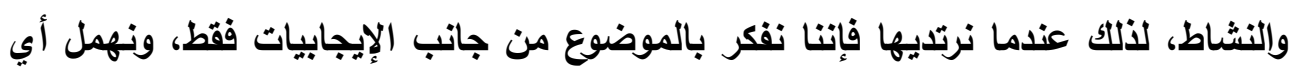
جانب آخر.

- قبعة التفكير السوداء: هذه القبعة يرتديها كثير من الناس عند تفكيرهم في مشكلة

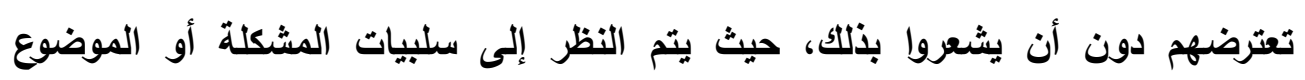
والصعويات والمشكلات المتعلقة بها. - قبعة التفكير الخضراء: اللون الأخضر لون الأثجار والتباتات التي تضفي جمالًا للمكان

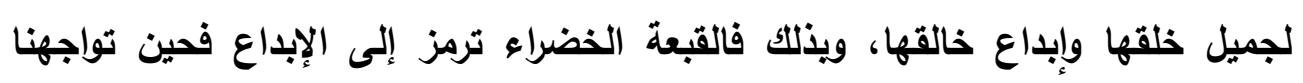

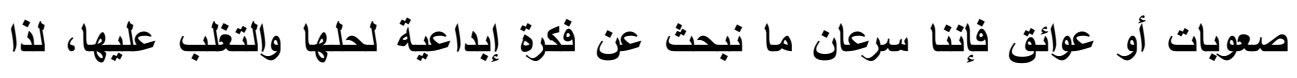

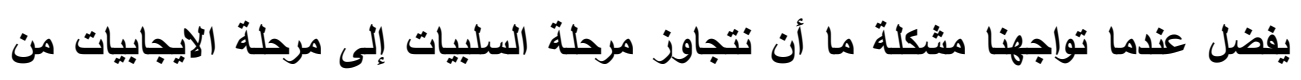

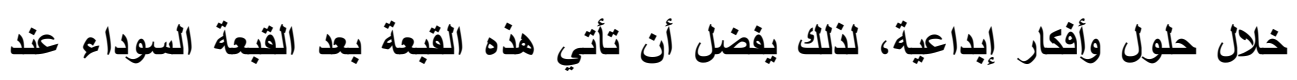

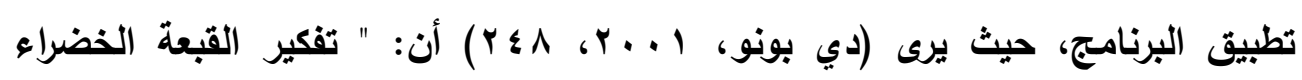
يستخدم للتظلب على أهداف القبعة السوداء".

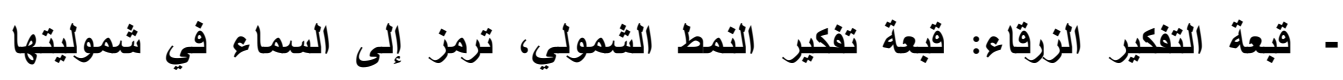

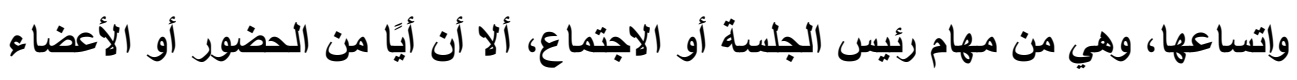

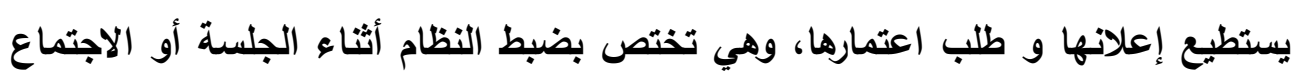

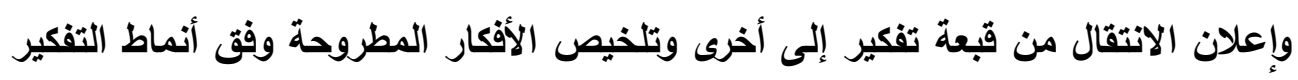

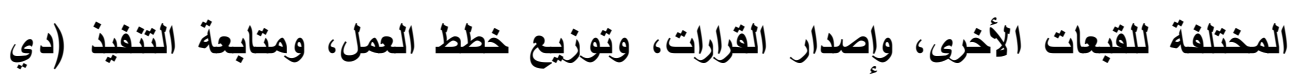

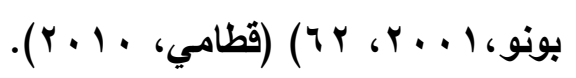

تطبيق برنامج قبعات التفكير الست في التعليم الجامعي:

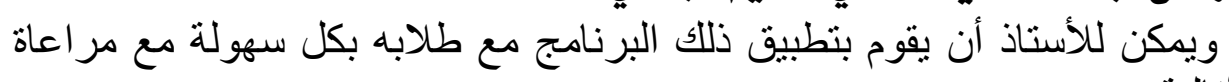

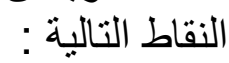

- ليس هناك ترتيب إلزامي معين للانتقال من نمط تفكير إلى آخر عند تطبيق هذا البرنامج.

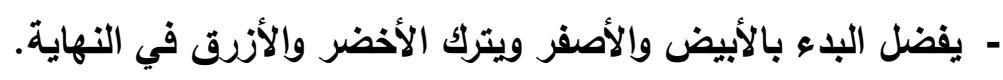
- لا توجد شروط أو قيود لأي قبعة تفكير باستثناء قبعة التفكير الحمراء يثترط فيها فيها ألا فئل تزيد فترة استخدامها عن · ب ثانية. 
وقد أثثت برنامج قبعات التفكير الست نجاحه وفاعليته في المجال التعليمي على المستوى المحلي والعالمي في عدد من الدراسات والبحوث العلمية.

اللدراسات السـابقة:

وجدت الباحثة العديد من الدراسات التي تناولت مهارة التحدث، وأخرى تناولت

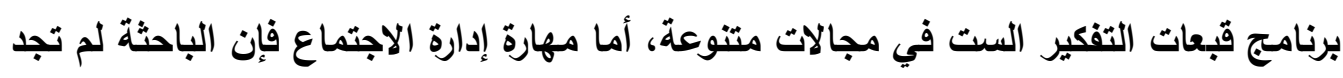
ـ على حد علمها _ دراسة سابقة تطرقت لهذه المهارة ، ويناء على ذلك صنفت الباحثة

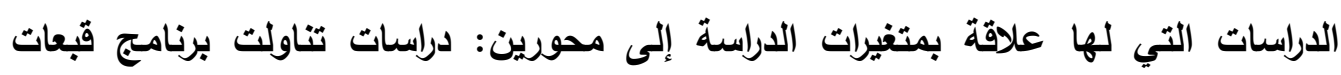
التفكير الست ودراسات تناولت مهارة التحدث، وفيما يلي تفصيل تلك الدراسات:

أولا - دراسات تناولت برنامج قبعات التفكير الست: من أبرز الدراسات التي تناولت برنامج قبعات التفكير الست ما يلئي: دراسة فاتح (fateh,2007) استهدفت معرفة أثر برنامج قبعات التفكير الست على فئل

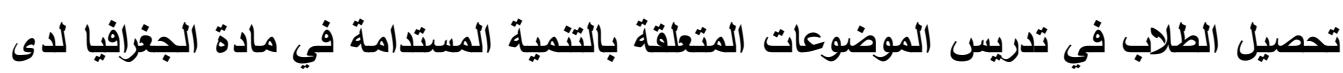
طلاب الصف الحادي عشر بتركيا، وإتخدم الباحث المنهج شبه التجريبي، واعتمد في أدواته

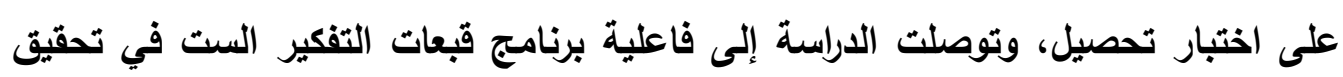
هدف الدراسة.

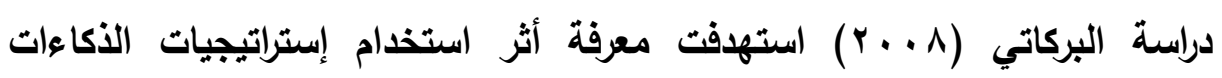

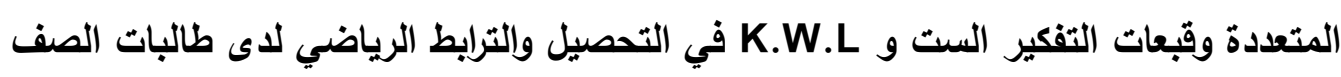
الثالث المتوسط، وتكونت عينة الدراسة من هودة طالبة تم تقسيمهم إلى ثلاث مجموعات مجموعة درست باستخدام إستراتيجية الأكاءات المتعددة، ومجموعة درست باستخدام برنامج

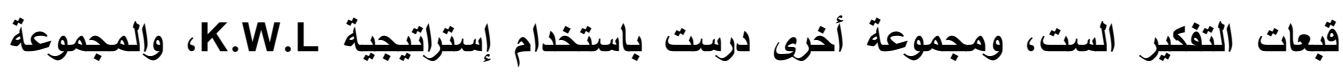
الرابعة كانت ضابطة، وقد استخدمت الباحثة المنهج شبه التجريبي، وكاتت أداتها البحثية عبارة عن اختبار تحليل التباين، وأثبتت نتائج الدراسة تفوق المجموعة التي درست باستخدام

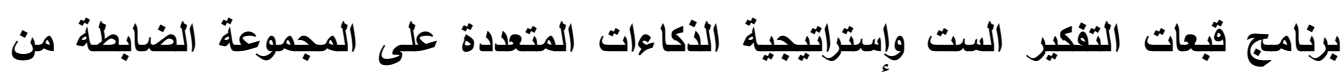
حيث مستوى الفهم والتواصل. دراسة العتيبي (9 . . . ) استهدفت التعرف على أثر إستراتيجية قبعات التفكير الست في

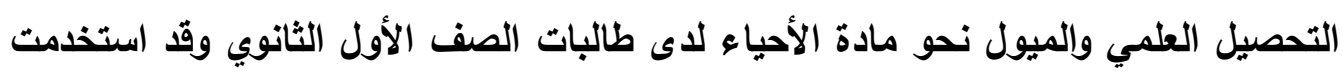


الباحثة المنهج شبه التجريبي، واعتمدت في أدواتها على اختبار للتحصيل ومقياس للميول، وتوصلت الاراسة إلى فاعلية الإستراتيجية المقترحة في تحقيق هدف الداعيدة الدراسة.

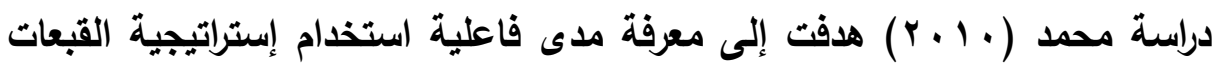
الست في تنمية مهارات القراءة الناقدة لاى طلاب الصف الأول الثانوي، واستخدمت الباحثة المنهج الوصفي التحليلي والمنهج شبه التجريبي، وتمثلت أدواتها البحثية في قائمة مهارات القراءة الناقدة واختبار تحصيلي لمهارات القراءة الناقدة، وقد أكدات نتائج الدراسة فاعلية استخدام إستراتيجية القبعات الست في تنمية مهارات القراءة الناقدة لاى طلاب المرحلة الثانوية.

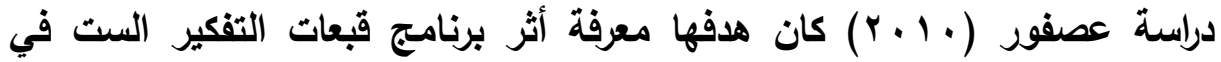
تجنب أخطاء التفكير وتنمية مهارة اتخاذ القرار لاى طلاب الصف الثالث الثانوي في مادة علم الاجتماع، واستخدمت الباحثة المنهج الوصفي التحليلي والمنهج شبه التجريبي، وإعتمت في أدواتها على اختبار المواقف الحياتية لأخطاء التفكير، ومقياس اتخاذ القرار لاى طالبات الصف الثالث الثانوي، وأثثتت الدراسة فاعلية برنامج قبعات التفكير الست في تجنب أخطاء التفكير وتنمية مهارة اتخاذ القرار. دراسة الخزرجي (11 ـ ب ) هدفت إلى معرفة أثر إستراتيجية قبعات التفكير الست في

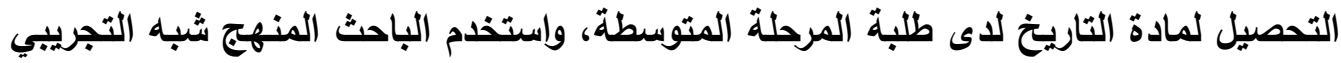
واعتمد على عدد من الاختبارات التحصيلية لتطبيقها في الاختبار البعدي، وقد أظهرت النتائج أثر برنامجج قبعات التفكير الست في زيادة تحصيل طلبة المرحلة المتوسطة في مادة التاريخ. دراسة جاهد، حكيم، جودت (Jahed , Hakeem , Godit, 2012) وكان هدفها معرفة أثر استخدام برنامج قبعات التفكير الست في تنمية مهارة الكتابة لدى طلاب الصف السادس الابتدائي بتركيا واستخدم الباحثون المنهج شبه التجريبي، ويلغ عدد أفر اد العينة . ب طالبًا وطالبة، وتم الاعتماد في الأدوات على اختبار للتحصيل، وتوصلت الدراسة إلى فاعلية برنامج قبعات التفكير الست في تحقيق هدف الدراسة.

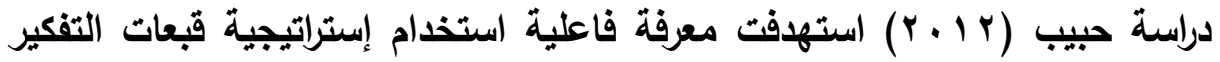
الست في تنمية التحصيل الهندسي والتفكير الناقد لاى طلاب الصف الثاني الإعدادي حيث استخلم الباحث المنهج شبه التجريبي، واعتمد في أدواته على اختبار التحصيل الهندسي 
واختبار مهارات التفكير الناقد، وقد أظهرت النتائج فاعلية استخدام إستراتيجية قبعات التفكير الست في تحقيق هدف الدراسة.

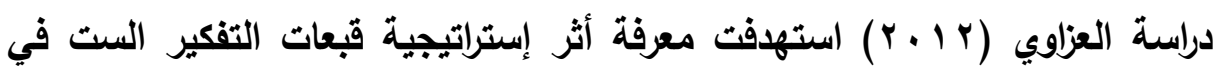
تحصيل مادة التربية الإسلامية لاى طلاب المرحلة الإعدادية، واعتمد الباحث على المنهج شبه التجريبي، وقد توصلت الدراسة إلى أثر إستراتيجية قبعات التفكير الست في تدريس التربية الإسلامية أكثر من الطرق المعتادة في التدريس، وأن المرحلة الإعدادية من المراحل التي يصلح تدريسها وفق إستراتيجية قبعات التفكير الست.

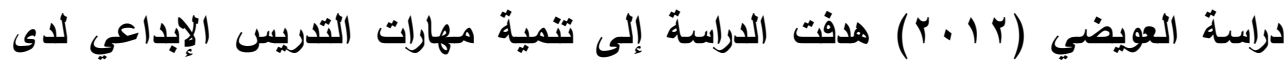

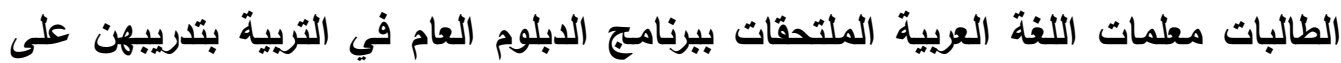
إستراتيجية التدريس القائمة على برنامج قبعات التفكير الست وتنمية اتجاههن نحوها واستخدمت الباحثة المنهج شبه التجريبي، واعتمدت في أدواتها على اختبار تحصيل ويطاقة ملاحظة ومقياس اتجاه، وقد أظهرت نتائج الاراسة فاعلية الوحدة الدراسية المقترحة القائمة على برنامج قبعات التفكير الست في تنمية التحصيل ومهارات التدريس الإبداعي والاتجاه نحوها لاى الطالبات معلمات اللغة العربية الملتحقات ببرنامج الدبلوم العام في التربية.

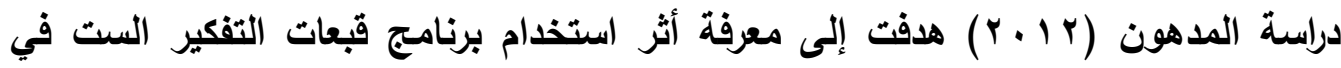

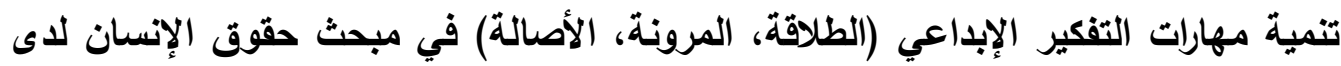
طلاب وطالبات الصف السادس الابتدائي بغزة، واستخدمت الباحثة المنهج شبه التجريبي واعتمدت في أدواتها على اختبار التفكير الإبداعي، وتوصلت الدراسة إلى فاعلية برنامج قبعات التفكير الست في تحقيق هدف الدراسة. ثانيًا ـ دراسات تناولت مهارة التحدث: دراسة أبو الغتم والمعايطة (9 . . . ) هدفت إلى معرفة مدى توافر مهارتي الحديث والإنصات وأثرهما في فاعلية الاتصال الإداري لاى الروئساء من وجهة نظر المرؤسبين

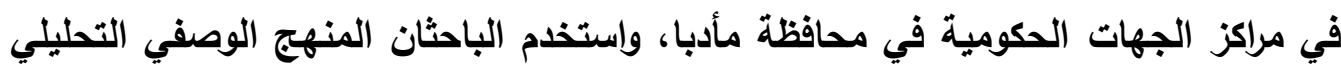
واعتمد الباحثان في أدواتهما على استبانة لمعرفة مدى توافر مهارتي الاستماع والحديث،

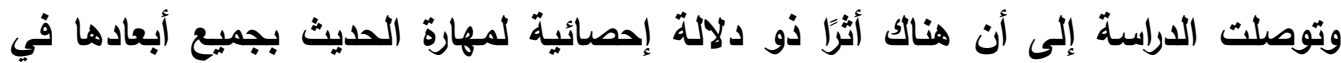
فاعلية الاتصال الإداري. 
وأعدت الغرياني (9 . . rم) دراسة هدفت إلى معرفة أثر برنامج مقترح في تثمية

مهارات التحدث لتلميذات الصف الخامس الابتائي في العاصمة صنعاء، وإستخدمت الباحثة المنهج التجريبي، وقد أظهرت النتائج أثر البرنامج المقترح في تنمية مهارات التحدث لطالبات

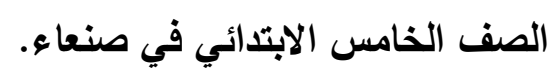

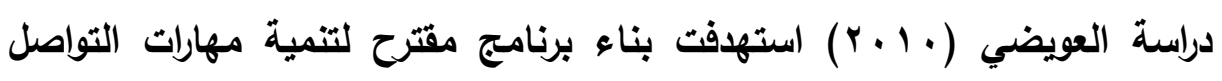

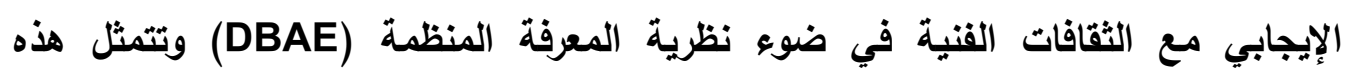
المهارات في الكتابة والتحدث والتعبير بالرموز التثكيلية التي يتم تدريب طالبات المرحلة الجامعية بالفرقة الرابعة لقسم التربية القنية على التواصل من خلالها مع الثقافة الفنية المتمثلة في الفن الإسلامي والمدارس الفتية الحديثة وفق محاور نظرية المعرفة المنظمة واستخدمت الباحثة المنهج شبه التجريبي، ولتحقيق هدف الدراسة قامت الباحثة بإعداد قائمة بمهارات التواصل الإيجابي اللفظية وغير اللفظية ومنها مهارة التحدث حيث

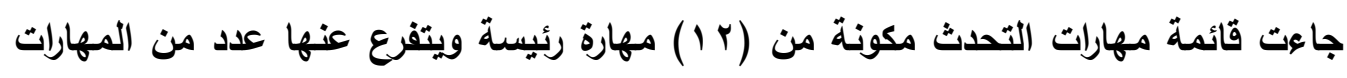
الفرعية، واختبارات لمهارات التواصل ويطاقات ملاحظة، وقات توصلت الدراسة إلى فاعلية البرنامج المقترح لتنمية مهارات التواصل الإيجابي في ضوء نظرية المعرفة المنظمة

(DBAE)

دراسة الناصر ( • ( ؟ ) هدفت إلى معرفة أثر التدريس باستخدام التقييم الحقيقي في التحصيل في قواعد اللغة العربية ومهارة التحدث لاى تلاميذ الصف السادس الابتدائي بالمملكة العربية السعودية، واستخدم الباحث المنهج شبه التجريبي، واعتمد الباحث في أدواته على اختبار تحصيل ومقياس تحدث، وتوصلت الدراسة إلى الحث على ضرورة تدريب معلمي اللغة العربية على استخدام التقييم الحقيقي في التدريس.

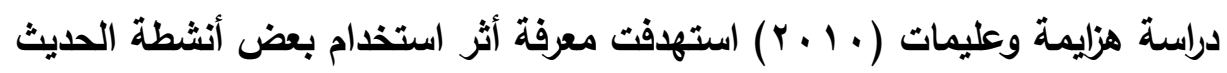
عن الأت في تنمية القدرة الكلامية لاى طلبة الصف الثاني الأساسي بالأردن واستخدم الباحثان المنهج شبه التجريبي، واعتمد الباحثان في أدواتهما على عدد من الأنشطة المقصودة التي تعتمد على الحديث عن الأات ويطاقة ملاحظة، وتوصلت الاراسة إلى أثر أنشطة الحديث عن الذات في تحقيق هدف الدراسة. 


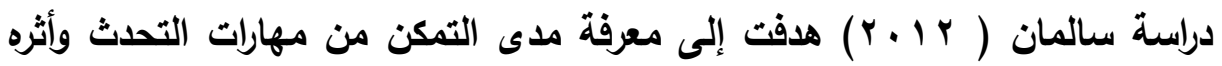
على تنمية مهارات الحوار وتقدير الذات لدى طلاب كلية التربية بالمملكة العربية السعودية واستخدم الباحث المنهج شبه التجريبي، واعتمد في أدواته على قائمة بمهارات التحدث واختبار مهارات التحدث، ويطاقة ملاحظة مهارات الحوار، ومقياس تقدير الأات، وتوصلت الدراسة إلى أن مهارات التحدث لها أثر واضح في تنمية تقدير الذات.

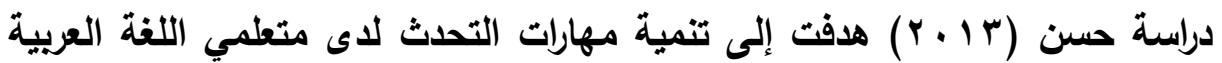
غير الناطقين بها باستخدام المدخل الوظيفي، واستخدم الباحث المنهج شبه التجريبي، وتكونت العينة من عدد من الطلاب غير العرب الوافدين إلى جامعة أسيوط لدراسة اللغة العربية ولتحقيق هدف الدراسة قام الباحث بتصميم استبيان بمهارات التحدث الوظيفي اللازمة لتعليم اللغة العربية لغير الناطقين بها، وأسفرت نتائج الاراسة عن فاعلية المدخل الوظيفي في تنمية مهارات التحدث لاى متعلمي اللغة العربية غير الناطقين بها. دراسة المحمدي (r ب ب) هدفت إلى التعرف على فاعلية الألعاب اللغوية في تنمية مهارات التحدث لاى طلاب الصف الأول المتوسط بالمملكة العربية السعودية ، واعتمد الباحث على المنهج شبه التجريبي، واعتمد الباحث في أدواته على قائمة بمهارات التحلث اللازمة لطلاب الصف الأول الابتدائي، واختبار مهارة التحدث، وقد توصلت الدراسة إلى فاعلية الألعاب اللغوية في تنمية مهارات التحدث لدى طلاب الصف الأول الابتدائي. التعقيب على اللدراسات السابقة: يتضح من عرض الدراسات السابقة ما يلي: - تثقت الدراسة الحالية مع الدراسات السابقة في أن برنامج قبعات التفكير الست من البرامج التي أثبتت أثرها وفاعليتها على المستوى العالمي والعربي والمحلي في مجالات ومراحل

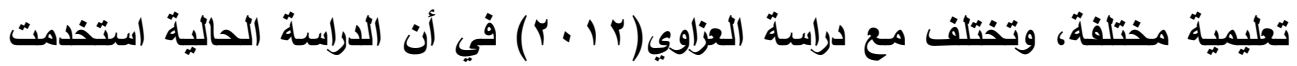
إستراتيجية قبعات التفكير الست في المرحلة الجامعية بدلا عن المرحلة الإعدادية . .

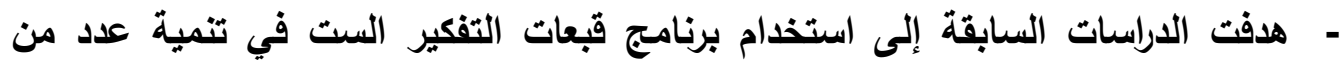

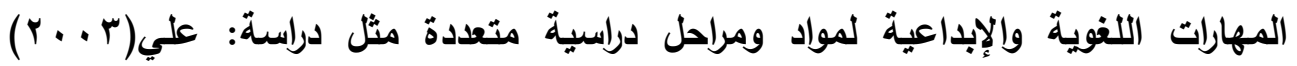

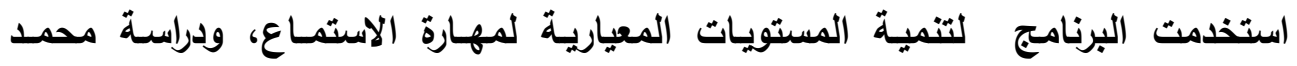

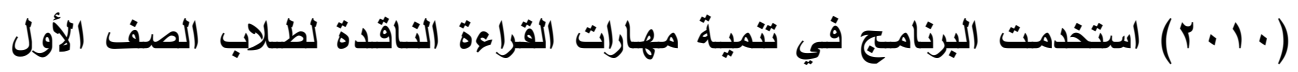


الثانوي، ودراسـة جـاهد وحكيـم وجــودت (Jahed , Hakeem , Godit, 2012) استخدمت البرنامج في تنمية مهارة الكتابة لطلاب السادس الابتدائي، و دراسة

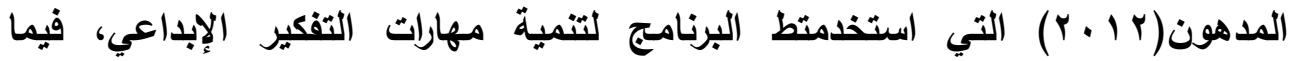
استهدفت دراسات أخرى تنمية وزيادة التحصيل في المواد والمراحل التعليمية المختلفة مثل مهل

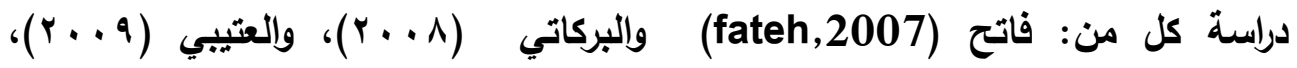

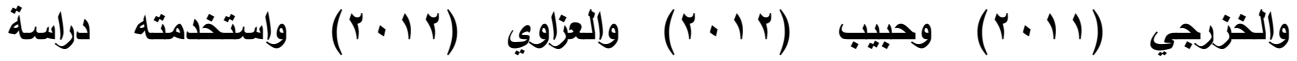

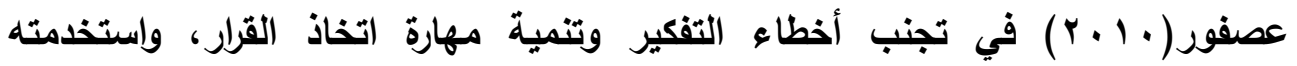

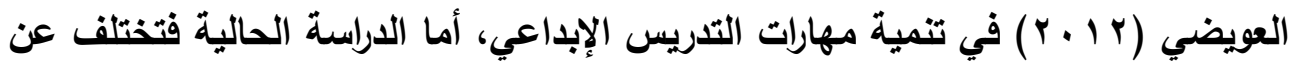
الاراسات السابقة في أنها تهذف إلى معرفة أثر إستراتيجية قائمة على برنامج قبعات التفكير الست لتنمية مهارة إدارة الاجتماع عند تدريس اللغة العربية بالمرحلة الجامعية ولم تجد الباحثة _على حد علمها ـ أي دراسة سابقة استخدمت هذه الإستراتيجية لتنمية تلك المهارة.

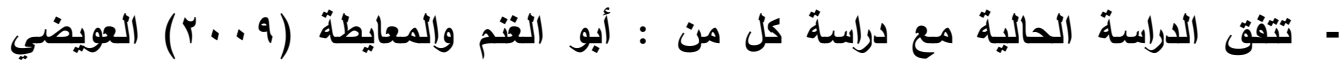

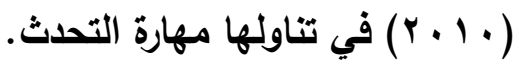

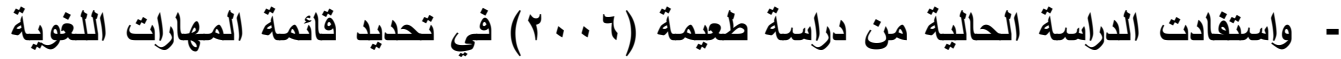
التي يحتاجها المتعلمون في مراحل التعليم الثلاث حيث جاءت هذه المهارات مقسمة إلى سبعة أقسام منها مهارة الكلام والتي تفرع منها أيضًا سبع مهارات فرعية أخرى، كما أفادت الاراسة من قائمة التواصل الإيجابي اللفظية وغير اللفظية في دراسة العويضي( • ( + ؟) حيث جاعت قائمة مهارات التواصل اللفظي مكونة من r I مهارة رئيسة ويتفرع منها عدد

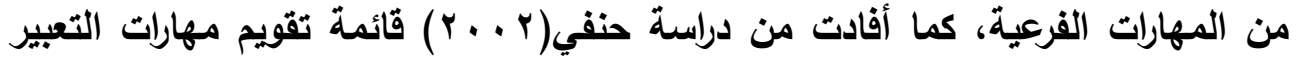
الشفهي اللازمة لطالبات الصف الأول الثانوي وفق الاتجاهات الحديثة وعدلت فيها لتناسب المرحلة الجامعية ، وقائمة مهارات الإتصال اللغوي الثفهي في دراسة

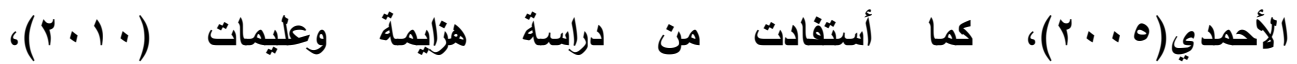

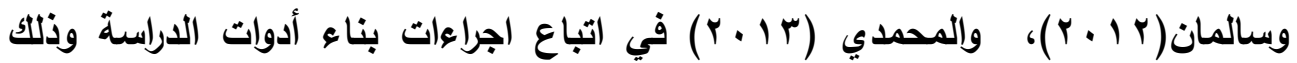
بتحديد مهارات التحدث بشكل عام ومن ثُّ تسنى للباحثة بناء قائمة مهارات إدارة الاجتماع 
كإحدى مهارات التحدث الفرعية، وكذلك الإفادة مما سبق في تصميم بطاقة تقويم مهارات إدارة الاجتماع.

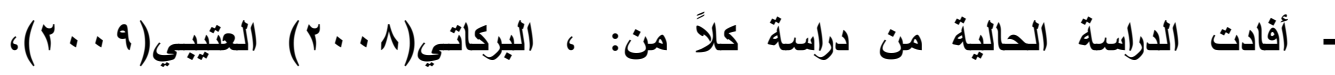
محمد(· +r)،

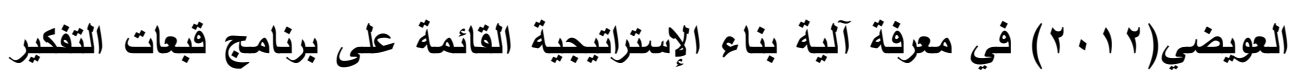
الست والتحقق من صدقها وثباتها وتطبيقها على عينة الدراسة. - أستفادت الدراسة الحالية من الدراسات السابقة في التعرف على خطوات استخدام المنهج على علئه

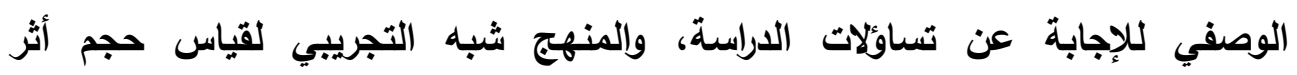
إستراتيجية التدريس القائمة على برنامج قبعات التفكير الست في تنمية مهارة إدارة الاجتماع لاى طالبات المرحلة الجامعية.

منهج اللدراسة و إجراءاتها

منهج الدراسة

- - - ماستخدمت الباحثة المنهج الوصفي للإجابة عن أسئلة الدراسة المتعلقة بمهارة إدارة

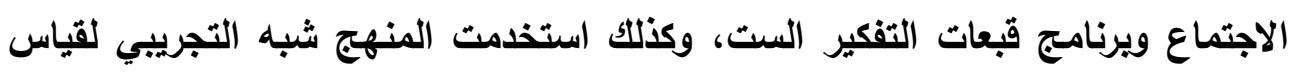

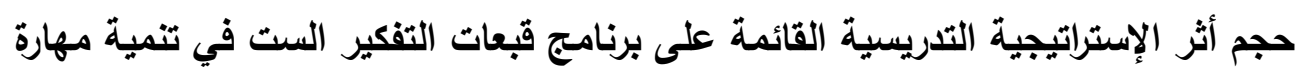

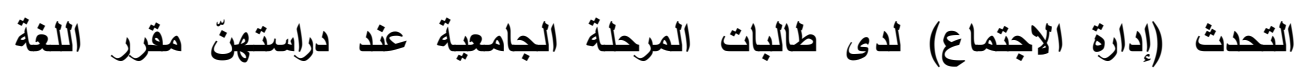

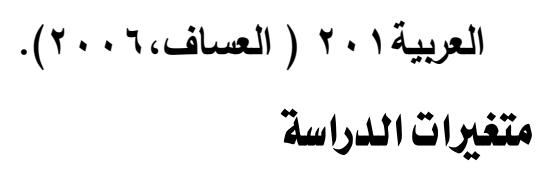

أ- المتغير المستقل: إستراتيجية التدريس القائمة على برنامج قبعات التفكير الست والتي تتضمن ما يلي: (الأهداف، المحتوى، أنشطة التعليم، أنشطة التعلم، مواد وأدوات الإستراتيجية و أدوات (التقويم) ب - المتغير التابع: مهارة إدارة الاجتمـاع، وتتضمن المهارات الفرعية التالية:( العرض والتقايم، والموضوعية في الطرح، والتعبير عن المشاعر، والحديث الفقّال أثناء الاجتماع،

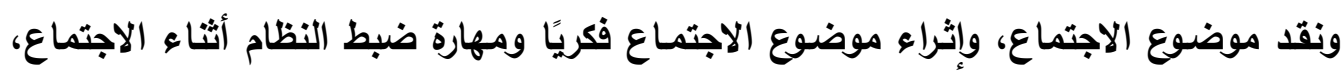
و حسن ختام الاجتماع) 


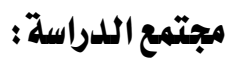

- تكون مجتمع الدراسة من طالبات جامعة الددود الثمالية المقيدات بمقرر اللغة العربية

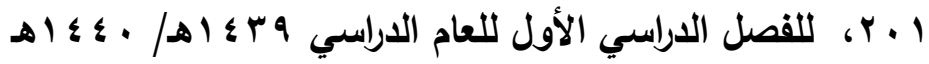

عينة الدراسة

تكونت عينة الدراسة من (ro ه) طالبة من الطالبات المسجلات بمقرر اللغة العربية بجامعة

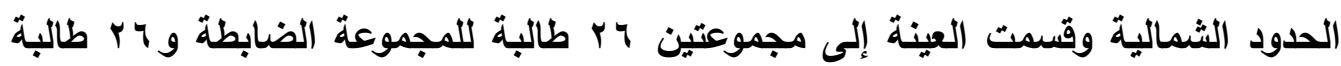
للمجموعة التجريبية، وقد اختارت الباحثة هذه العينة لأنها الطالبات بهذه المرحلة العمرية

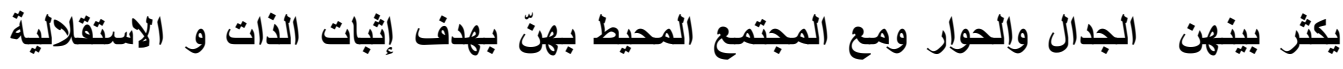
والتفرد، كما تزداد قدرتهنّ على حل المشكلات وإصدار الأحكام واتخاذ القرارات؛ لذا فإن تطبيق التيق

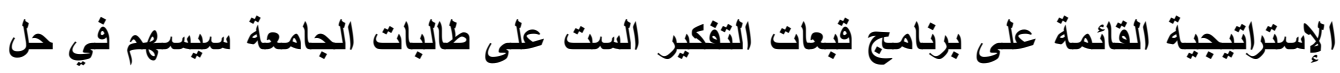
كثير من المثكلات الذاتية والاجتماعية التي قد تعترضهن عند اتخاذ القرارات أو إصدار

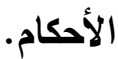

أدوات ومواد الدراسة

اعتمدت الباحثّة في هذه الاراسة على المواد التالية:

قائمة المهارات الفرعية لمهارة إدارة الاجتماع بمقرر اللفة العربية. الإستراتيجية التريسية القائمة على برنامج قبعات التفكير الست لتنمية مهارة التحدث

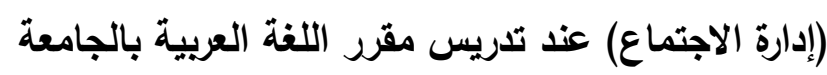

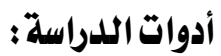

بطاقة تقويم مهارات إدارة الاجتماع عند تعليم اللغة العربية لطالبات المرحلة الجامعية. وفي ما يلي عرض إجراءات بناء المواد والأدوات: أولًا - قائمة بالمهارات الفرعية لمهارة إدارة الاجتماع: اـ الهاف من القائمة: تحديد المهارات الفرعية لمهارة إدارة الاجتماع المناسبة لطالبات

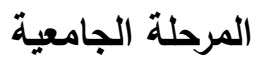
Y - مصادر بناء القائمة: تم بناء القائمة استنادًا على المصادر التالية: 


\section{أثر إستراتيجية تدريس قائمة على برنامج قبعات النفكير الست للنمية مهارات التحدث (إدارة الاجتماع) ..........}

أولًا- الكتب التريوية المتخصصة في مجال مهارات اللغة العربية وطرق تدريسها، بالإضافة إلى الكتب المتخصصة في إدارة الأعمال بصفة عامة وإدارة الاجتماعات بصفة خاصة ومن هذه الكتب: كتاب أحمد فؤاد عليان (المهارات اللغوية ماهيتها وطرائق تنميتها)، وكتاب كمال زعفر علي (القراءة والمحادثة في ضوء منهج تكاملي)، وكتاب مدحت أبو النصر (إدارة وتنظيم الاجتماعات كمدخل لتطوير العمل بالمنظمة ) وكتاب محمد حجاب (مهارات الاتصال للإعلاميين والتريويين والدعاة) . ثانيًا - نتائج البحوث واللدراسات العلمية التي تناولت مهارات التحلث ومنها دراسة

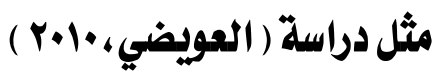
r. الصورة الأولية للقائمة: جاعت مهارات إدارة الاجتماع في صورتها الأولية في (^)

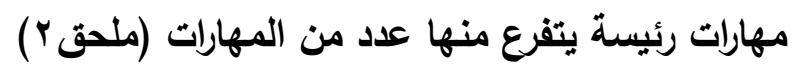

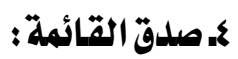
تم التأكد من صدق القائمة وشمولها لمهارات إدارة الاجتماع ومدى ملائمتها لبرنامج قبعات التفكير الست، ومدى وضوح صياغتها، بإجراء أمرين: الأول - مراجعة القائمة والتأكد من شمولها، ومدى ملائمتها لبرنامج قبعات التفكير الست ودرجة وضوح صياغتها. الثاني- صدق المحكمين، وذلك بعرض القائمة على متخصصين في قسم المناهج وطرق التدريس العامة، ومناهج وطرق تدريس اللغة العربية، ومتخصصين في قسم الإدارة والاقتصاد ملحق(r) وقد طُب من المحكمين إبداء الرأي حول مدى ملائمة القائمة

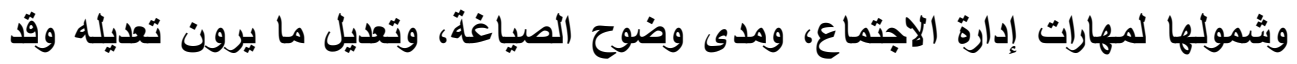
أثار المحكمون إلى تعديل صياغة بعض المهارات الفرعية، ودمج بعض المض المهارات بمهارات أخرى منعًا للتكرار، وقد تم الأخذ بالتعديلات التي أشار بها المحكمن سواء بالامج أو الحذف أو الإضافة. ه- الصورة النهائية للقائمة: توصلت الباحثة إلى الصورة النهائية لقائمة مهارات إدارة الاجتماع لتطبيق إستراتيجية التتريس القائمة على برنامج قبعات التفكير الست لاى طالبات الصف الثالث المتوسط عند تعليم اللفة العربية حيث تكونت من قائمتين: قائمة مهارات إدارة 
الاجتماع لرؤساء الاجتماع وقائمة مهارات إدارة الاجتماع لأعضاء الاجتماع. ملحق (؛)

- مانيًا - بطاقة تقويم مهارات إدارة الاجتماع :

1- الهذف منها : صممت الباحثة بطاقة ملاحظة لتقويم أداء الطالبات مهارات إدارة

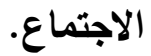

r- الصورة الأولية لبطاقة تقويم مهارات إدارة الاجتماع : جاعت الصورة الأولية لبطاقة

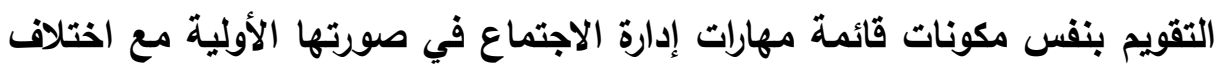
في التصميم حيث تكونت البطاقة من مهارات إدارة الاجتماع الرئيسة بالاتجاه الأفقي ثم يندرج تحت كل مهارة رئيسة عدد من المهارات الفرعية بنفس الاتجاه، وفي الاتجاه الرأسي أسماء الطالبات بحيث توضع الدرجة المستحقة لكل طالبة أمام كل

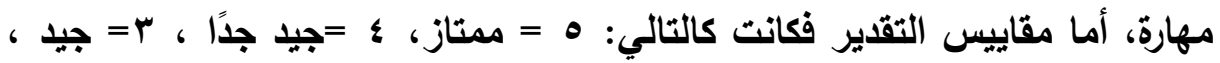
r r- صدق بطاقة تقويم مهارات إدارة الاجتماع: تم التأكد من صدق بطاقة الملاحظة

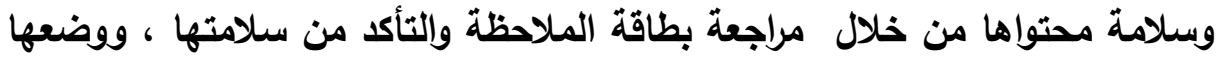
في استفتاء تم عرضه على محكمين في قسم المناهج وطرق التدريس العامة ومناهج وطرق تدريس اللغة العربية وقسم الإدارة والتخطيط، إلى أن تم إخراجها

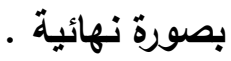
؛ - ثبات بطاقة تقويم مهارات الاجتماع : تم تطبيق بطاقة التقويم على عينة استطلاعية

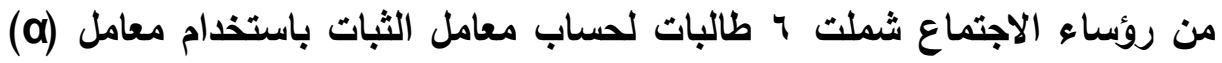

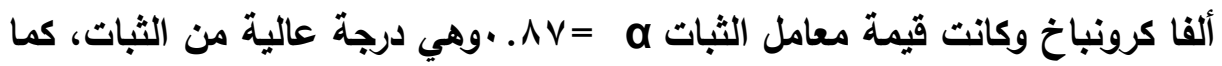
تم حساب معامل ثبات مهارات إدارة الاجتماع لأعضاء الاجتماع بتطبيقها على عينة

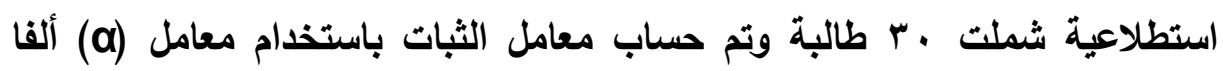

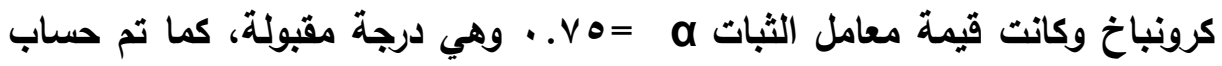
معاملات الارتباط (سبيرمان) بين كل مهارة من مهارات إدارة الاجتماع الفرعية بيطاقة التقويم و البطاقة ككل وذلك لحساب قيم معاملات الاتساق الداخلي لأبعاد بطاقة التقويم لرؤساء الاجتماع كما يوضحه الجدول التالي: 


\section{أثر إستراتيجية تدريس قائمة على برنامج قبعات التفكير الست لتنمية مهارات التحدث (إدارة الاجتماع) ...........}

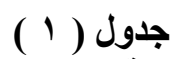

الاتساق الداخلي لأبعاد بطاقة ملاحظة لمهارات إدارة الاجتماع لرؤساء الاجتماع

\begin{tabular}{|c|c|}
\hline - معاملات الارتباط & - المهارات \\
\hline$* * . . \wedge \wedge=$ & - العرض والتقليم \\
\hline$* * . \wedge r=$ & - الموضوعية في الطرح \\
\hline$* * . V Y=$ & - ـ التعبير عن المشاعر \\
\hline$* *, . \wedge .=$ & ـ الحديث الفعال أثثاء الاجتماع \\
\hline$* * .9 r=$ & - قد موضوع الاجتماع \\
\hline$* * . .71=$ & - إثراء موضوع الاجتماع فكريًا \\
\hline$* * . . \vee 7=$ & - ضبط النظام أثناء الاجتماع \\
\hline$* * . \vee \wedge=$ & - حسن ختام الاجتماع \\
\hline
\end{tabular}

يتبين من الجدول السابق أن جميع معاملات الارتباط كانت دالة عند مستوى

ا +., ، مما يدل على درجة عالية من الاتساق للأداة.

كما تم حساب معاملات الارتباط (بيرسون) بين كل مهارة من مهارات إدارة الاجتماع الفرعية ببطاقة التقويم والبطاقة ككل وذلك لحساب قيم معاملات الاتساق الاخلي لأبعاد بطاقة التقويم لأعضاء الاجتماع موضحة بالجدول التالي:

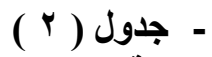

\begin{tabular}{|c|c|}
\hline - معاملات الارتباط & - المهارات \\
\hline$* * \cdot .91=$ & - الموضوعية في الطرح \\
\hline$* * . \Delta r=$ & - التعبير عن المشاعر \\
\hline$* * \cdot . V \leq-$ & - الحديث الفعال أثناء الاجتماع \\
\hline$* * . . \vee V=$ & - نقد موضوع الاجتماع \\
\hline$* * . .71=$ & - إثراء موضوع الاجتماع فكريًا \\
\hline
\end{tabular}

تبين من الجدول السابق أن جميع معاملات الارتباط كانت دالة عند مستوى 1 ـ., . مما يدل على درجة عالية من الاتساق للأداة. وللتأكد من تكافؤ المجموعتين الضابطة والتجريبية (رؤساء الاجتماع) في التطبيق القبلي لبطاقة ملاحظة مهارات الاجتماع تم استخدام الاختبار اللابارامتري مان ويتني (Mann Whitney) والجدول التالي يوضح 


$$
\text { جدول (r) }
$$

نتائج اختبار مان ويتنى (Mann Whitney) للتطبيق القبلي لبطاقة تقويم رؤساء

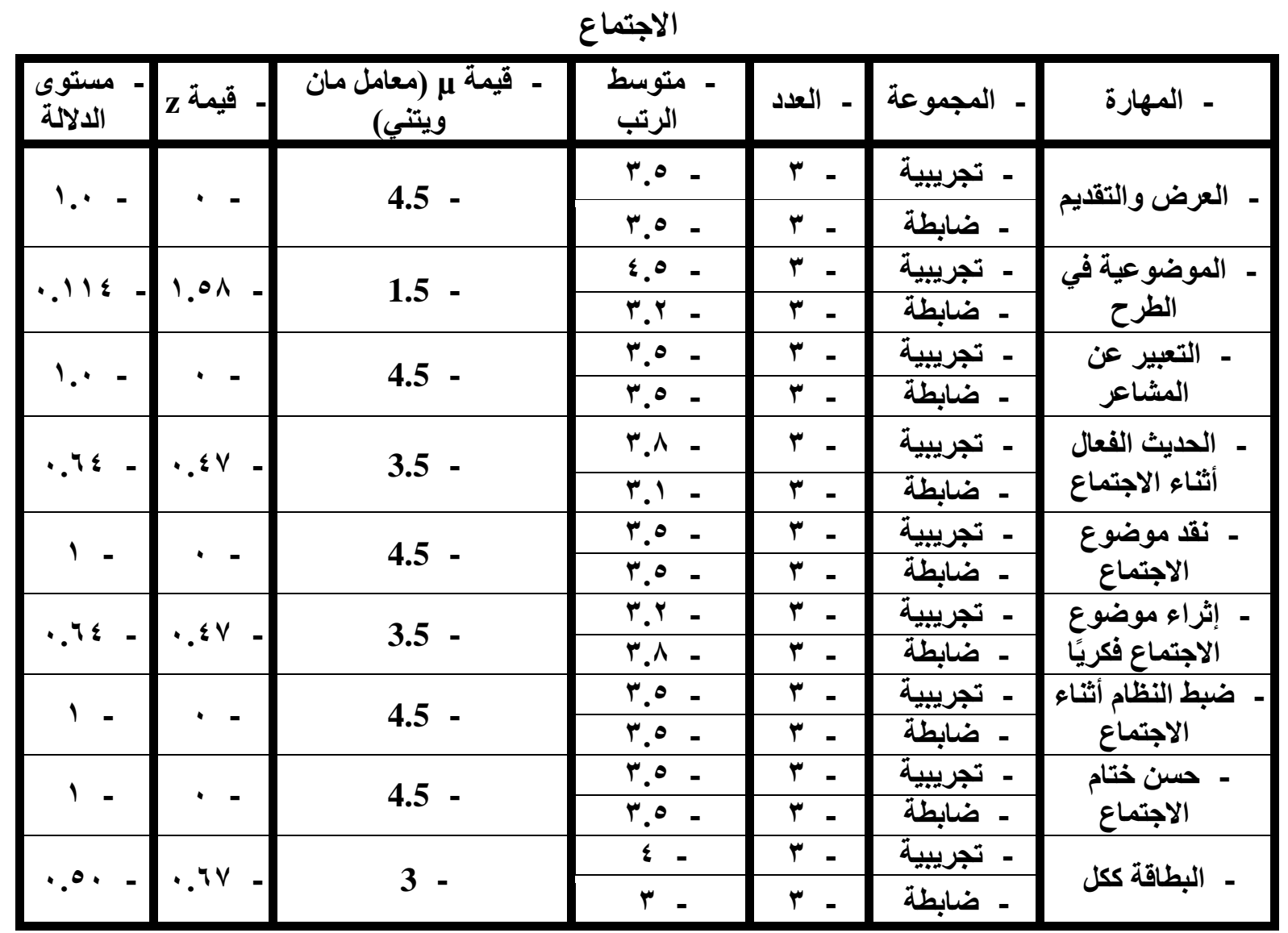

يلاحظ من الجدول أن جميع قيم على عدم وجود فروق بين المجموعتين الضابطة والتجريبية في التطبيق القبلي لبطاقة الملاحظة . وللتأكد من تكافؤ المجموعتين الضابطة والتجريبية (أعضاء الاجتماع) في التطبيق القبلي لبطاقة ملاحظة مهارات الاجتماع تم استخدام اختبار (ت) T. test والجدول التالي يوضح نتائج الاختبار: 


\section{أثر إستراتيجية تدريس قائمة على برنامج قبعات التفكير الست لتنمية مهارات التحدث (إدارة الاجتماع) ...........}

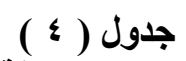

اختبار (ت) T. test للتطبيق القبلي لبطاقة (الملاحظة لأعضاء الاجتماع

\begin{tabular}{|c|c|c|c|c|c|c|c|}
\hline الدلالة & قيمة ت & - & - الالمعراف & المتوسط & ــ العدد & ـ المجموعة & - المهارة \\
\hline$\cdot \leqslant V$ & $\because V r=$ & o. - & $\begin{array}{l}1.0 V= \\
. .20=\end{array}$ & $\begin{array}{l}r . r 0= \\
.11=\end{array}$ & $\begin{array}{l}\text { Yq }- \\
4=-\end{array}$ & - - تجريبية & - الموضوعية في \\
\hline $1=$ & $\cdot$ & o. & $\begin{array}{l}\cdot- \\
\cdot-\end{array}$ & $\begin{array}{l}r= \\
r=\end{array}$ & $\begin{array}{l}\text { rq } \\
\text { rq }\end{array}$ & - ت ضريبية & - التببير عن \\
\hline$\Lambda r_{.-}=$ & . & o. - & $\frac{. .89-}{. \vee V \cdot-}$ & E.ro & $\frac{-}{47-}$ & - - تجريبية & ' الحديث الفعال أثناء \\
\hline - & 1. & o. - & $\frac{.197=}{\because \cdot-}$ & $\frac{r . \cdot \varepsilon=}{r . \cdot-}$ & $\frac{\text { rq }}{\text { rq }}$ & - - تجريبية & - الاجتماعوع \\
\hline . & $\because \varepsilon V-$ & o. - & $\frac{.00=}{. .7 \leq=}$ & $\begin{array}{l}\text { r.r. }= \\
\text { r.ru }=\end{array}$ & $\frac{\text { rq }}{\text { rq }}$ & - - تجريبية & - إثراع موضوع فكريًا \\
\hline .09 & \& & o. - & $\frac{1.71=}{1.79=}$ & $\frac{\mid \leq . \cdot \varepsilon=}{|r . \wedge|}$ & $\frac{r+}{r+}$ & - - تجريبية & - البطاقة ككل \\
\hline
\end{tabular}

من الجدول السابق نلاحظ أن جميع قيم ت غير دالة إحصائيا مما يال على عدم وجود فروق بين المجموعتين الضابطة والتجريبية في التطبيق القبلي لبطاقة الملاحظة على أعضاء الاجتماع، و ذلك يلال على أن المجموعتين التجريبية والضابطة متكافئتان. الصورة النهائية لبطاقة ملاحظة مهارات إدارة الاجتماع: تم تقسيم بطاقة تقويم مهارات إدارة الاجتماع إلى بطاقتين وفق ما أثشار إليه بعض المحكمين الأولى- خاصة بمهارات إدارة الاجتماع لرؤساء الاجتماع، والثانيةخاصة بمهارات إدارة الاجتماع لأعضاء الاجتماع والملحقين (†) و (V) يوضحان الشكل النهائي لبطاقتيّ تقويم المهارات. إجراءات وخطوات تطبيق بطاقة تقويه مهارات إدارة الاجتماع: أ. القائمة بالتطبيق: تم تطبيق بطاقة الملاحظة في الاختبار القبلي والبعدي لكلا المجموعتين

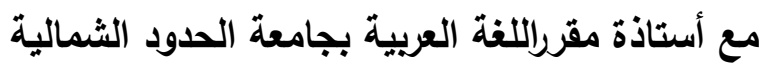


ب ـ آلية التطبيق: بعد انتهاء عملية التعليم للمجموعتين الضابطة والتجريبية تم تقسيم طالبات الشعبة المكوّن من (Yr) طالبة في كلا المجموعتين إلى ثلاث مجموعات بحيث لا

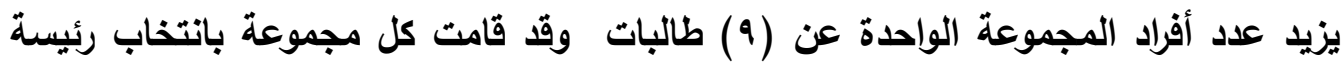
اجتماع لها من نفس المجموعة، ثم عقدت كل مجموعة اجتماعها حول موضوع معين تم

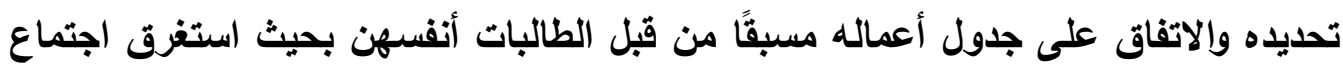
المجموعة الواحدة (0؛) دقيقة من زمن المحاضرة المحدد بثلاث ساعات، وعند بداية الاجتماع قامت الباحثة وأستاذة المقرر بملاحظة أداء الطالبات أثناء إدارة الاجتماع ورصد أدهد الارجات لكل طالبة في بطاقة تقويم مهارات إدارة الاجتماع.

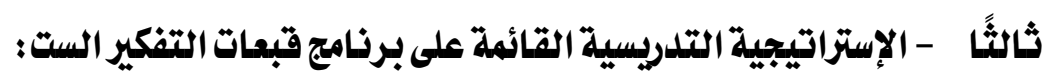
1- الهدف منها: تنمية مهارة إدارة الاجتماع لاى عينة الدراسة.

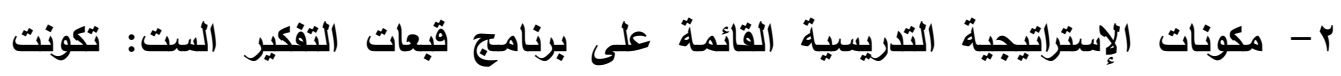
الإستراتيجية من الأهداف، المحتوى التعليمي، أنشطة التعليم وأنشطة التعلم، ومن مواد وأدوات الإستراتيجية، ووسائل التقويم، وقد اعتمدت الباحثة في تنمية مهارة إدارة الاجتماع عدة موضوعات تلامس واقع حياة الطالبات واهتماماتهن من اختيارهن :وهي (تحديد تكليفات مقرر اللغة العربية، سلبيات وإيجابيات وسائل التواصل الاجتماعي، كتابة مقال، كتابة تقرير).

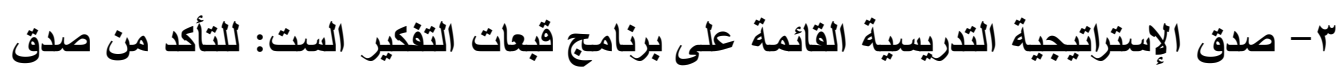

$$
\text { الإستراتيجية قامت الباحثة بما يلي: الإسئية }
$$

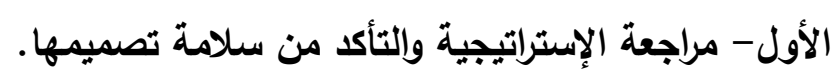
الثاني- وضعها بصورتها الأولية وعرضه على عينة المحكمين في قسم المناهج وطرق التدريس العامة ومناهج وطرق تدريس اللغة العربية ثم أجرت الباحثة التعديلات التي عينة

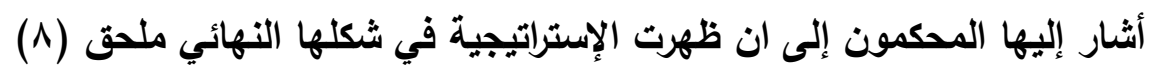
؟ - خطوات تطبيق الإستراتيجية : - تعريف أستاذة مقرر اللغة العربية باجراءات تطبيق إستراتيجية التدريس القائمة على برنامج قبعات التفكير الست وطريقة استخدام بطاقة تقويم الطالبات في مهارات إدارة

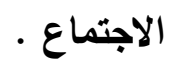
- تطبيق بطاقة تقويم مهارات إدارة الاجتماع على عينتي الدراسة الضابطة والتجريبية. 


\section{أثر إستراتيجية تدريس قائمة على برنامج قبعات النفكير الست لتنمية مهارات التحدث (إدارة الاجتماع) ..........}

- تطبيق الإستراتيجية التدريسية المقترحة على المجموعة التجريبية أما المجموعة الضابطة فدرست بالطريقة الاعتيادية. - تطبيق بطاقة تقويم مهارات إدارة الاجتماع على كلا المجموعتين ثم رُصدت الدرجات

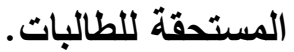
- استغرق تطبيق الإستراتيجية المقترحة على عينة الدراسة ؛ أسابيع بواقع 1 ساعات دراسية ، (r) ساعة دراسية لكل أسبوع، للتعليم للتطبيق والتقييم ابتاءع من يوم الأحد

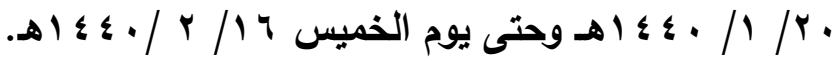
- حظيت الإستراتيجية أثناء تطبيقها على استحسان أستاذة مقرر اللغة العربية.

ثتائج الدراسة أ- التحقق من فروض الدراسة: أولًا - التحقق من صحة الفرض الأول:

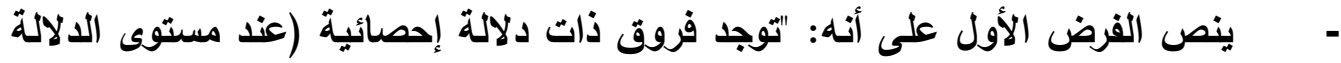

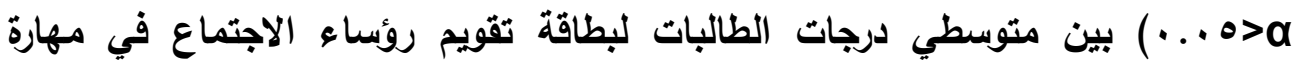
العرض والتقديم في المجموعتين التجريبية والضابطة لصالح المجموعة التجريبية" ولاختبار صحة هذا الفرض تم استخدام اختبار مان ويتنى (Mann Whitney) لحساب قيم M لحساب الفروق في التطبيق البعدي لبطاقة تقويم مهارة العرض والتقديم للمجموعتين التجريبية والضابطة والجدول التالي يوضح نتائج الاختبار :

$$
\text { جدول (o) }
$$

نتائج اختبار مان ويتنى (Mann Whitney) للتطبيق البعدي لبطاقة تقويم مهارة العرض

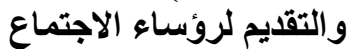

\begin{tabular}{|r|r|r|r|r|r|r|}
\hline & - \\
\hline & - & - \\
\hline
\end{tabular}

من الجدول السابق نلاحظ أن جميع قيم ر (معامل مان ويتني)، وقيمة z لها دلالة إحصائية عند مستوى اقل من ه ... مما يدل على وجود فروق بين المجموعتين الضابطة والتجريبية في التطبيق البعدي لمهارة العرض والتقديم، ويالتالي قبول الفرض 
الأول، وتعزى هذه التتيجة العالية إلى أن الطالبات اعتمرن قبعة التفكير البيضاء التي

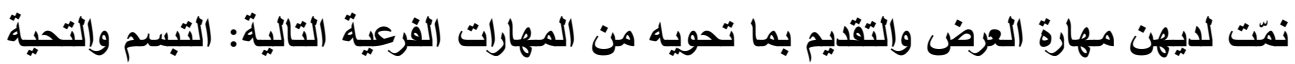
في بداية الاجتماع والتعريف بالرئيس والأعضاء والترحيب بهم، عرض موضوع الاجتماع وجدول الأعمال وقد اتفقت هذه النتيجة مي الدراسات السابقة التي أظهرت أثر الاستراتيجية في تنمية مهارة التحدث في التفاعل الاجتماعي والاتصال الإداري مثل: دراسة

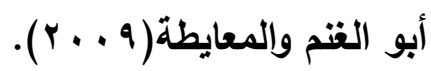

- - ثانياً - التحقق من صحة الفرض الثاني:

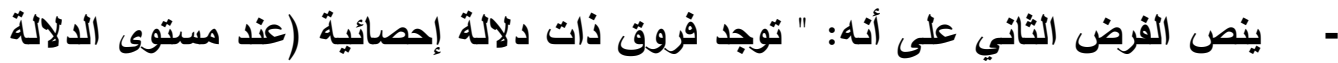

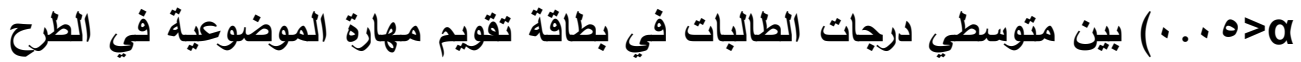

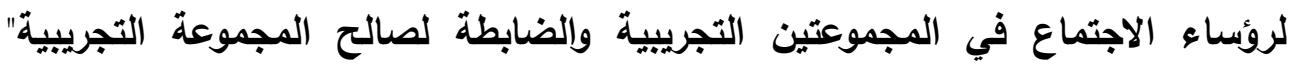
ولاختبار صحة هذا الفرض تم استخدام اختبار مان ويتنى Whitney Mann) لحساب قيم ر لحساب الفروق في التطبيق البعدي لبطاقة تقويم مهارة الموضوعية في الطرح لاى رؤساء الاجتماع بالمجموعتين التجريبية والضابطة والجدول التالي يوضح نتائج الاختبار :

$$
\text { جدول (7) }
$$

نتائج اختبار مان ويتنى (Mann Whitney) للتطبيق البعدي لبطاقة تقويم مهارة الموضوعية في لوأي

\begin{tabular}{|c|c|c|c|c|c|c|}
\hline الدلالة & قيمة & 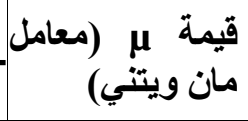 & الرتب & العدد & المجموعة . & المهارة \\
\hline. $.1 r$ & 1.97 & 1.0 & $\varepsilon .0$ & $r$ & تجريبية & \multirow{2}{*}{ في الطرحوعية } \\
\hline & & & r.o & $r$ & ضابطة & \\
\hline
\end{tabular}
الطرح لرؤساء الاجتماع للانطي لئاع

من الجدول السابق نلاحظ أن جميع قيم مستوى أكبر من هـ... مما يدل على عدم وجود فروق بين المجموعتين الضابطة والتجريبية في التطبيق البعدي لمهارة الموضوعية في الطرح وما يتفرع عنها من مهارات فرعية، هذا فيما يخص رؤساء الاجتماع أما أعضاء الاجتماع فالنتائج كالتالي: 


\section{أثر إستراتيجية تدريس قائمة على برنامج قبعات التفكير الست لتنمية مهارات التحدث (إدارة الاجتماع) ..........}

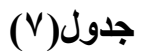

نتائج اختبار (ت) للتطبيق البعدي لبطاقة تقويم مهارة الموضوعية في الطرح لأعضاء الاجتماع

\begin{tabular}{|l|r|r|r|r|r|r|r|}
\hline المهارة - & - \\
\hline
\end{tabular}

دلت قيمة ت على وجود فروق بين المجموعتين الضابطة والتجريبية أعضاء الاجتماع في التطبيق البعدي لمهارة الموضوعية في الطرح و ما يتفرع عنها من مهارات فرعية وهذه الفروق دالة إحصائيًا عند مستوى اقل من ا ب... مما يعني قبول الفرض الثاني فيما يخص نتائج أعضاء الاجتماع والذي يدل على أن إستراتيجية التدريس القائمة على لفي برنامج قبعات التفكير الست لها أثر في تنمية مهارة الموضوعية في الطرح بين أعضاء الاجتماع ولصالح المجموعة التجريبية، وقد ظهرت الفروق بين أعضاء الاجتماع ولم تظهر لاى روئساء الاجتماع في المجموعة التجريبية بسبب ضرورة وحتمية التزام الرئيس بالإيجاز في طرح الفكرة وإعطاء وقت أطول للأعضاء لعرض جميع أفكارهن باعتمار قبعة التفكير البيضاء وما تتطلبه مهارة الموضوعية من عرض الحقائق والمعلومات المتعلقة بموضوع الاجتماع كما هي دون تفسير أو تحليل وعرض الحقائق والمعلومات بعيدًا عن الآراء والعواطف الشخصية. ثالثاً - التحقق من صحة الفرض الثالث: ينص الفرض الثالث على أنه: " توجد فروق ذات دلالة إحصائية (عند مستوى الدلالة م> هa المجموعتين التجريبية والضابطة لصالح المجموعة التجريبية " ولاختبار صحته تم استخدام اختبار مان ويتنى (Mann Whitney) لحساب قيم M لحساب الفروق في التطبيق البعدي في بطاقة تقويم مهارة التعبير عن المشاعر لاى رؤساء الاجتماع بالمجموعتين التجريبية والضابطة والجدول التالي يوضح نتائج الاختبار: 


\section{أثر إستراتيجية تدريس قائمة على برنامج قبعات النفكير الست لتنمية مهارات التحدث (إدارة الاجتماع) ...........}

$$
\text { جدول) (^) }
$$

نتائج اختبار مان ويتنى (Mann Whitney) للتطبيق البعدي لبطاقة تقويم مهارة التعبير عن المشاعر لرؤساء الاجتماع البطي

\begin{tabular}{|l|c|c|c|c|c|c|c|}
\hline - & - \\
\hline & - & - & - \\
\hline
\end{tabular}

من الجدول السابق نلاحظ أن جميع قيم إحصائية عند مستوى أقل من ه ... مما يدل على وجود فروق بين المجموعتين الضابطة والتجريبية في التطبيق البعدي لمهارة التعبير عن المشاعر وما يتفرع منها من مهارات

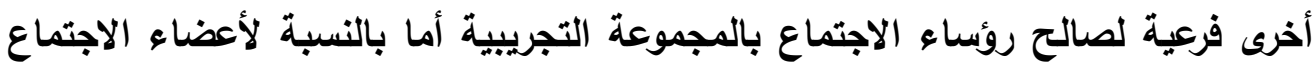

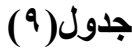
فالنتائج كالتالي:

نتائج اختبار ت للتطبيق البعدي لبطاقة تقويم مهارة التعبير عن المشاعر لأعضاء الاجتماع

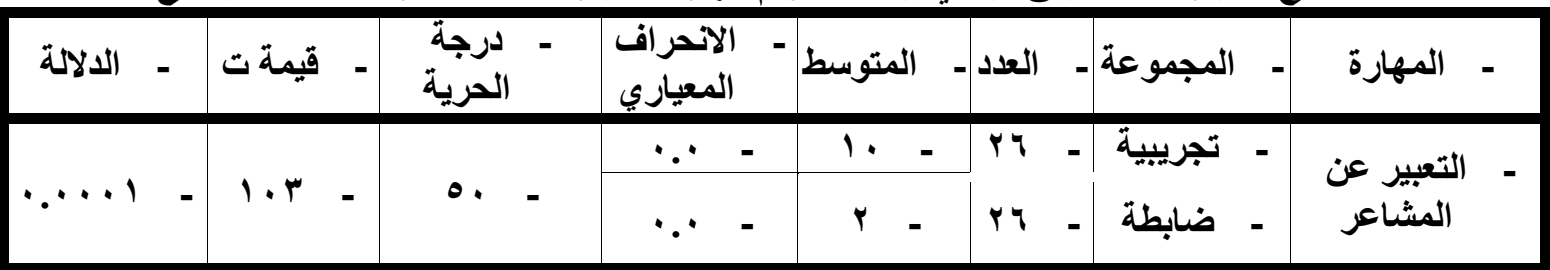

دلت قيمة ت على وجود فروق بين المجموعتين الضابطة والتجريبية أعضاء

الاجتماع في التطبيق البعدي في مهارة التعبير عن المشاعر وهذه الفروق دالة إحصائيًا عند مستوى اقل من ا ب. .. وهذا يعني قبول هذا الفرض مما يعني أثر إستراتيجية برنامج قبعات التفكير الست في تنمية مهارة التعبير عن المشاعر بين رؤساء وأعضاء الاجتماع

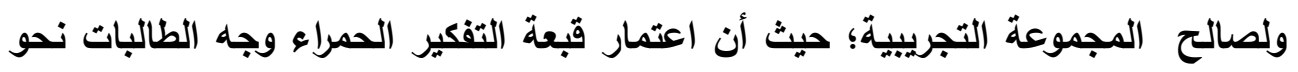
توضيح مشاعرهن وميولهن بقبول أو رفض الفكرة في ما لا يتجاوز ·ـ ثانية وهذا ما

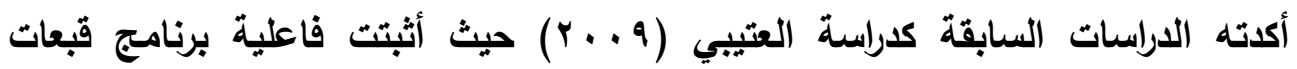
التفكير الست في التعبير عن الميول. 


\section{أثر إستراتيجية تدريس قائمة على برنامج قبعات التفكير الست لتنمية مهارات التحدث (إدارة الاجتماع) ..........}

رابعاً - التحقق من صحة الفرض الرابع:

ينص الفرض الرابع على أنه: " توجد فروق ذات دلالة إحصائية (عند مستوى

الالالة ه>ه ... ب بين متوسطي درجات الطالبات في بطاقة تقويم مهارة الحديث الفعال

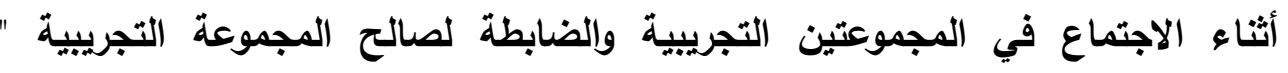
ولاختبار صحة هذا الفرض تم استخدام اختبار مان ويتنى (Mann Whitney) لحساب قيم ر لحساب الفروق في التطبيق البعدي لبطاقة تقويم مهارة الحديث الفعال أثناء الاجتماع لاى رؤساء الاجتماع بالمجموعتين التجريبية والضابطة والجدول التالي يوضح

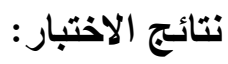

$$
\text { جدول(:) }
$$

نتائج اختبار مان ويتنى (Mann Whitney) للتطبيق البعدي لبطاقة تقويم مهارة الحديث الفعال أثناء الاجتماع لرؤساء الاجتماع البعاع ليطاع

\begin{tabular}{|c|c|c|c|c|c|c|c|}
\hline الدلالة & - & قيمة & قيمة ب مان ومعامل & متوسط & العدد & المجموعة . & المهارة \\
\hline \multirow{2}{*}{\multicolumn{2}{|c|}{$\cdot, \cdot \leq \quad-$}} & & & & $r$ & تجريبية & \multirow{2}{*}{ الحديث الفعال أثناء } \\
\hline & & 1,99 & $\cdot, \cdots$ & $r$. & $r$ & ضابطة & \\
\hline
\end{tabular}

من الجدول السابق نلاحظ أن جميع قيم إحصائية عند مستوى اكبر من ه. .. . مما يدل على وجود فروق بين المجموعتين الضابطة

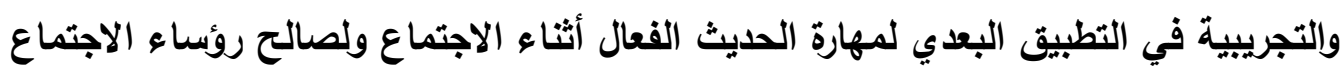
بالمجموعة التجريبية وهذا يعني قبول الفرض الرابع فيما يخص رؤساء الاجتماع، أما بالنسبة لأعضاء الاجتماع فالنتيجة كالتالي: بأنهو

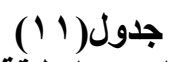

نتائج اختبار (ت) للتطبيق البعدي لبطاقة تقويم مهارة الحديث الفعال

\begin{tabular}{|c|c|c|c|c|c|c|c|}
\hline الدلالة & قيمة ت & الحرية & الالحيرافي & المتوسط & العدد & المجموعة & المهارة \\
\hline \multirow{2}{*}{$\because \cdots+$} & \multirow{2}{*}{ rV.A } & \multirow{2}{*}{0 . } & $.9 \mathrm{~V}$ & 19.41 & \multirow{2}{*}{$\begin{array}{l}\text { Y } \\
\text { rq }\end{array}$} & تجريبية & \multirow{2}{*}{ الفعال أثنثاء } \\
\hline & & & $1 . \varepsilon r$ & r. 1 & & ضابطة & \\
\hline
\end{tabular}

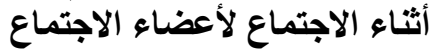

دلت قيمة ت على وجود فروق بين المجموعتين الضابطة والتجريبية لأعضاء الاجتماع في التطبيق البعدي في مهارة الحديث الفعال أثناء الاجتماع وهذه الفروق دالة 
إحصائيًا عند مستوى اقل من ا ... مما يعني قبول الفرض الرابع فيما يخص أعضاء

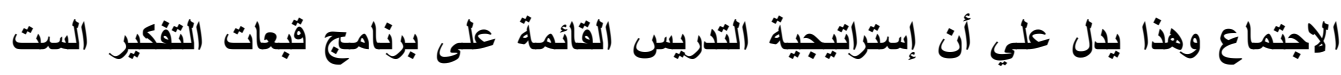

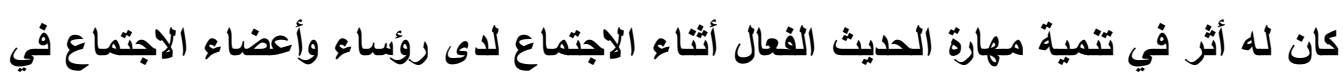
المجموعة التجريبية، ويعزى ذلك إلى اعتمار الطالبات قبعة التفكير الصفراء التي تنطلب منهن عرض الإيجابيات والفوائد المتعلقة بموضوع الاجتماع واستخدام لغة الجسد، وعدم الخروج عن موضوع الاجتماع والاستدلال بالتجارب الناجحة وهذا اتفق مع دراسة البركاتي

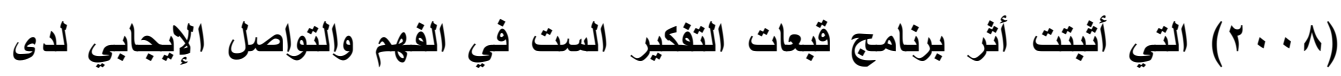

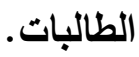

\section{خامساً - التحقق من صحة الفرض الخامس :}

ينص الفرض الخامس على أنه: " توجد فروق ذات دلالة إحصائية (عند مستوى الدلالة

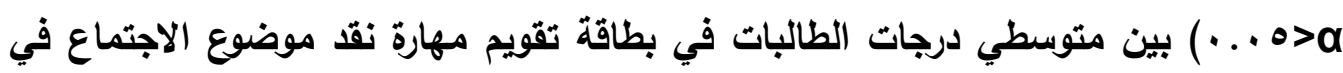

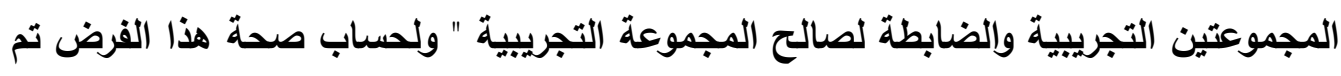
استخدام اختبار مان ويتنى (Mann Whitney) لحساب قيم M لحساب الفروق في التطبيق البعدي لبطاقة الملاحظة في مهارة نقد موضوع الاجتماع لاى رؤيساء الاجتماع بالمجموعتين التجريبية والضابطة والجدول التالي يوضح نتائج الاختبار : -

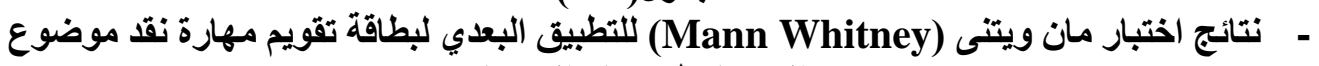

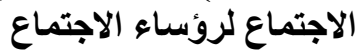

\begin{tabular}{|c|c|c|c|c|c|c|c|c|}
\hline الدلالة & - & قيمة & قمان ويتني) & متوسط الرتب & العدد & & المجموعة & المهارة \\
\hline \multirow[t]{2}{*}{0.025} & \multirow[t]{2}{*}{-} & \multirow[t]{2}{*}{$2.24-$} & \multirow{2}{*}{$0.00-$} & & & - & تجريبية & \multirow{2}{*}{ نقا موضوعاع } \\
\hline & & & & & $r$ & - & ضابطة & \\
\hline
\end{tabular}

من الجدول السابق نلاحظ أن جميع قيم

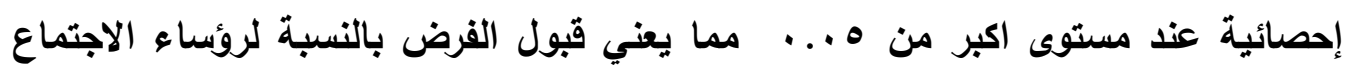

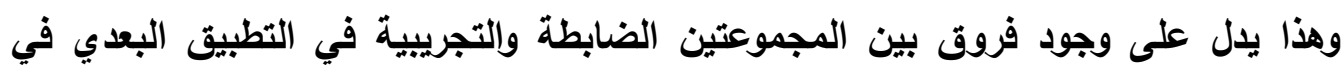
مهارة نقد موضوع الاجتماع ولصالح رؤساء الاجتماع بالمجموعة التجريبية أما بالنسبة فئية لأعضاء الاجتماع فالإجابة كالتالي: مواع الاجناع 


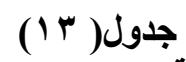

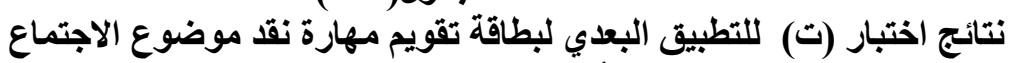

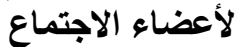

\begin{tabular}{|l|c|c|c|c|c|c|c|c|}
\hline - & - & - & - \\
\hline
\end{tabular}

دلت قيمة ت على وجود فروق بين المجموعتين الضابطة والتجريبية أعضاء

الاجتماع في التطبيق البعدي في مهارة نقد موضوع الاجتماع وهذه الفروق دالة إحصائيًا عند مستوى اقل من ا ب... مما يعني قبول الفرض الخامس بالنسبة لأعضاء الاجتماع أيضًا وهذا يدل على أن برنامج قبعات التفكير الست لله أثر في تنمية مهارة نقد موضوع

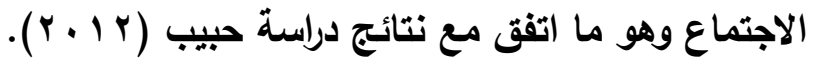

$$
\begin{aligned}
& \text { سادساً - التحقق من صحة الفرض السادس : }
\end{aligned}
$$

ينص الفرض السادس على أنه: " توجد فروق ذات دلالة إحصائية (عند مستوى الدلالة

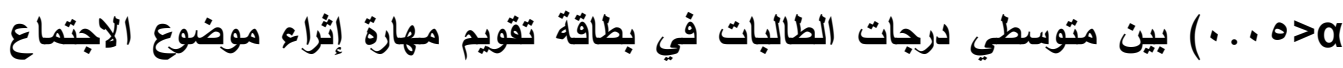
فكريًا في المجموعتين التجريبية والضابطة لصالح المجموعة التجريبية " تم استخدام اختبار مان ويتنى (Mann Whitney) لحساب قيم تقويم مهارة إثراء موضوع الاجتماع فكريًا لاى رؤساء الاجتماع بالمجموعتين التجريبية

والضابطة والجدول التالي يوضح نتائج الاختبار:

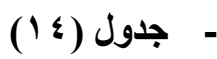

- - نتائج اختبار مان ويتني (Mann Whitney) للتطبيق البعدي لبطاقة تقويم مهارة

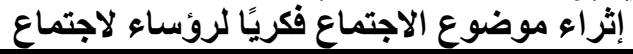

\begin{tabular}{|l|c|c|c|c|c|c|c|}
\hline - & - \\
\hline
\end{tabular}

من الجدول السابق نلاحظ أن جميع قيم إحصائية عند مستوى أكبر من هن ... مما يدل على وجود فروق بين المجموعتين الضابطة والتجريبية في التطبيق البعدي لمهارة إثراء موضوع الاجتماع فكريًا ولصالح 
رؤساء الاجتماع بالمجموعة التجريبية مما يعني قبول الفرض السادس بالنسبة لرؤساء

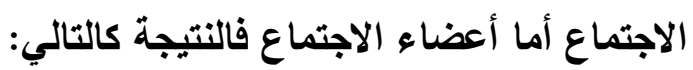
-

- - نتائج اختبار ت للتطبيق البعدي لبطاقة تقويم مهارة إثراء موضوع الاجتماع فكريًا لأعضاء الاجتماع أرضوع

\begin{tabular}{|c|c|c|c|c|c|c|c|c|c|}
\hline - & - \\
\hline
\end{tabular}

دلت قيمة ت على وجود فروق بين المجموعتين الضابطة والتجريبية أعضاء الاجتماع في التطبيق البعدي لمهارة إثراء موضوع الاجتماع فكريًا وهذه الفروق دالة

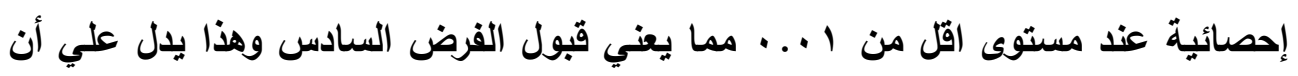
إستراتيجية التدريس القائمة على برنامج قبعات التفكير الست لها أثر في فئون تنمية مهارة إثراء موضوع الاجتماع فكريًا لاى رؤساء وأعضاء الاجتماع وذلك لاعتمارهن قبعة التفكير الخضراء التي تنمي مهارة عرض مقترحات من إبداع الطالبات تثري موضوع الاجتماع

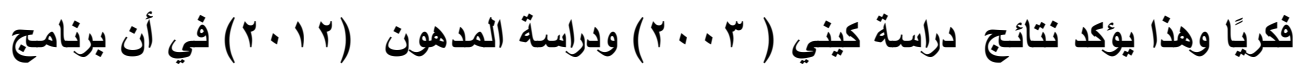
قبعات التفكير الست له أثر في تنمية التفكير الإبداعي لدى الطلبة التهابة سابعاً - التحقق من صحة الفرض السابع : ينص الفرض السابع على أنه: " توجد فروق ذات دلالة إحصائية (عند مستوى الدلالة له>a النظام أثناء الاجتماع في المجموعتين التجريبية والضابطة لصالح المجموعة التجريبية " ولاختبار صحة الفرض تم استخدام اختبار مان ويتنى (Mann Whitney) لحساب قيم لحساب الفروق في التطبيق البعدي لبطاقة الملاحظة في مهارة ضبط النظام أثناء الاجتماع لرؤساء الاجتماع بالمجموعتين التجريبية والضابطة والجدول التالي يوضح نتائج فيط الاختبار: 


\section{أثر إستراتيجية تدريس قائمة على برنامج قبعات النفكير الست لتنمية مهارات التحدث (إدارة الاجتماع) ...........}

\section{-}

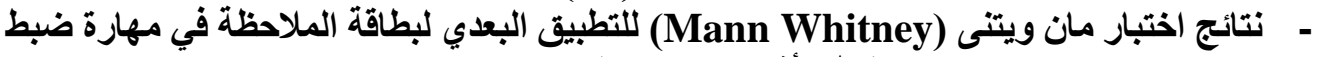
النظام أثناء الاجتماع لرؤساء الاجتماع ليطاع

\begin{tabular}{|c|c|c|c|c|c|c|}
\hline الالالة & z قيمة & - قيمة مان ويتني) & - & العدد & - المجموعة & المهارة \\
\hline \multirow{2}{*}{$\cdot \cdot \varepsilon r$} & \multirow{2}{*}{$r_{0} \cdot r r=$} & \multirow{2}{*}{$\because \cdots=$} & & & - تجريبية & \multirow{2}{*}{ ضبط النظام } \\
\hline & & & r & $r$ & ضابطة & \\
\hline
\end{tabular}

من الجدول السابق نلاحظ أن جميع قيم إحصائية عند مستوى أقل من ه... . مما يعني قبول الفرض السابع وهذا يدل على وجود فروق بين المجموعتين الضابطة والتجريبية في التطبيق البعدي لمهارة ضبط النظام أثناء الاجتماع ولصالح رؤساء الاجتماع بالمجموعة التجريبية، وهذا يعزى لاعتمار الطالبات رؤساء

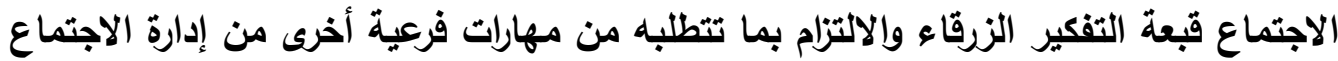
وتجنب هلره بما لا يثري موضوع الاجتماع، تنظيم الحوار وعدم المقاطعة، العدل في توزيع المشاركة على جميع الأعضاء.

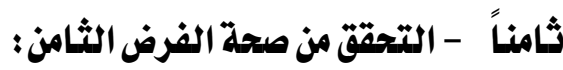
ينص الفرض الثامن على أنه: " توجد فروق ذات دلالة إحصائية (عند مستوى الدلالة اله ه>a الاجتماع في مهارة حسن ختام الاجتماع في المجموعتين التجريبية والضابطة لصالح Mann ) المجموعة التجريبية " ولاختبار صحة هذا الفرض تم استخدام اختبار مان ويتنى (Whitney لحساب قيم M لحساب الفروق في التطبيق البعدي لبطاقة الملاحظة في مهارة حسن ختام الاجتماع لرؤساء الاجتماع بالمجموعتين التجريبية والضابطة والجدول التالي

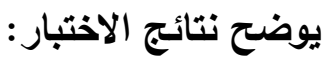




\section{أثر إستراتيجية تدريس قائمة على برنامج قبعات التفكير الست لتنمية مهارات التحدث (إدارة الاجتماع) ..........}

$$
\text { (IV) جدول) }
$$

نتائج اختبار مان ويتنى (Mann Whitney) للتطبيق البعدي لبطاقة تقويم مهارة حسن ختام

$$
\text { الاجتماع لرؤساء الاجتماع للائم الإع }
$$

\begin{tabular}{|c|c|c|c|c|c|c|c|c|}
\hline ا ل الدلالة & - & z قيمة & - قيمة ب مان ويتني) & - متوسط الرتب & العدد & المجموعة & - & المهارة \\
\hline$\because \cdot r \varepsilon$ & - & r.Ir & $\because \cdots$ & $0 \quad-$ & $r$ & تجريبية & - & \multirow[t]{2}{*}{ حسن ختام الاجتمـاع } \\
\hline & & & & $r \quad$ & $r$ & ضابطة & - & \\
\hline
\end{tabular}

من الجدول السابق نلاحظ أن جميع قيم إحصائية عند مستوى أقل من ه ... وهذا بعني قبول القرض الثامن، مما يدل على وجود فروق بين المجموعتين الضابطة والتجريبية في التطبيث البعدي لمهارة حسن ختام الاجتماع ولصالح رؤساء الاجتماع بالمجموعة التجريبية وذلاك يعود إلى اعتمارهن قبعة التفكير الزرقاء وما تتطلبه من تلخيص ما دار في الاجتماع وإعلان القرارات وتوزيع الخطط ومسؤليات التنفيذ وشكر الأعضاء، وهذه النتيجة تؤكد نتائج دراسة عصفور ( ( • ( ) في أثر برنامج قبعاث التفكير الست في تتمية مهارة اتخاذ القرار. تاسعاً - التحقق من صحة الفرض التاسع: ينص الفرض التاسع على أنه: " توجد فروق ذات دلالة إحصائية (عند مستوى الدلالة ه ه . . . ) بين متوسطي درجات الطالبات في بطاقة تقويم لمهارات إدارة الاجتماع ككل في المجموعتين التجريبية والضابطة لصالح المجموعة التجريبية" ولاختبار صحته تم استخدام اختبار مان ويتنى (Mann Whitney) لحساب قيم لبطاقة الملاحظة لمهارات إدارة الاجتماع ككل لاى رؤساء الاجتماع بالمجموعتين التجريبية والضابطة والجدول التالي يوضح نتائج الاختبار: جدول(1) (1)

نتائج اختبار مان ويتنى (Mann Whitney) للتطبيق البعدي في بطاقة تقويم مهارات إدارة

\begin{tabular}{|c|c|c|c|c|c|c|}
\hline الالالة & قيمة z & قيمة ب مان و معامل & متوسط الرتب & العدد & المجموعة & المهارة \\
\hline \multirow[t]{2}{*}{$\because 0}$. & \multirow[t]{2}{*}{1.97} & \multirow[t]{2}{*}{$\because \cdot$} & 0 & $r$ & تجريبية & \multirow{2}{*}{ الاجتماع كهل إدارة } \\
\hline & & & $r$ & $r$ & ضابطة & \\
\hline
\end{tabular}

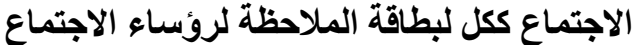


من الجدول السابق نلاحظ أن جميع قيم M (معامل مان ويتني)، وقيمة z لها دلالة إحصائية عند مستوى أقل من ه .. . مما يعني قبول الفرض التاسع وهذا يال على وجود فروق بين المجموعتين الضابطة والتجريبية في التطبيق البعدي لبطاقة التقويم ككل ولصالح رؤساء الاجتماع بالمجموعة التجريبية، أما بالنسبة لأعضاء الاجتماع فالنتائج كالتالي:

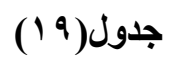

نتائج اختبار ت للتطبيق البعدي في مهارات إدارة الاجتماع ككل لبطاقة تقويم أُعضاء الاجي متهماع

\begin{tabular}{|c|c|c|c|c|c|c|c|}
\hline الدلالة & قيمة ت & درجة الحرية & الالمعياري & المتوسط & العدد & |المجموعة & المهارة \\
\hline \multirow{2}{*}{$\because \cdots \cdot$} & \multirow{2}{*}{$7 . . r$} & \multirow{2}{*}{0 . } & $\cdot .97$ & $7 \leqslant . T$ & rq & تجريبية & \multirow{2}{*}{ الاجتمارع ككل } \\
\hline & & & T.70 & 19.70 & ץ & ضابطة & \\
\hline
\end{tabular}

دلت قيمة (ت) على وجود فروق بين المجموعتين الضابطة والتجريبية أعضاء الاجتماع في التطبيق البعدي لبطاقة الملاحظة ككل، وهذه الفروق دالة إحصائية عند مستوى اقل من I. .. مما يدل علي أن إستراتيجية التدريس القائمة على برنامج قبعات التفكير الست لها أثر في تنمية مهارات إدارة الاجتماع ككل لاى رؤساء وأعضاء الاجتماع بالمجموعة التجريبية

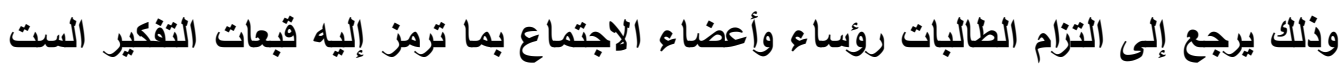

عند اعتمارهن لها.

\section{عرض نتائج أسئلة}

النتيجة الأولى: تمثل إجابة السؤل الفرعي الأول من أسئلة الاراسة ونصه: س ا - ما قائمة مهارات إدارة الاجتماع لروئساء الاجتماع ولأعضاء الاجتماع اللازم تنميتها

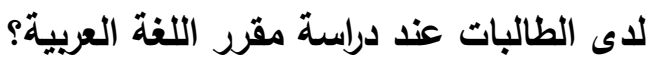
توصلت هذه الدراسة إلى قائمة مهارات إدارة الاجتماع، وقد تم تقسيم هذه القائمة إلى قائمتين:

الأولى - مهارات إدارة الاجتماع لرؤساء الاجتماع.

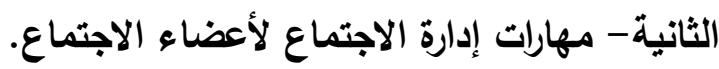
أما مهارات إدارة الاجتماع لرؤساء الاجتماع فهي كالتالي: 


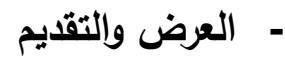

- التبسم والتحية في بداية الاجتماع.

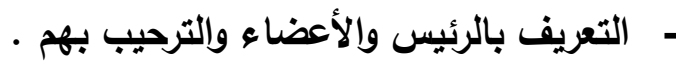

- عرض موضوع الاجتماع وجدول الأعمال.

ب - الموضوعية في الطرح

- عرض الحقائق والمعلومات المتعلقة بموضوع الاجتماع كما هي دون تفسير أو تحليل

- عرض الحقائق والمعلومات بعيدًا عن الآراء والعواطف الشخصية

ج - التعبير عن المثاعر

- التعبير عن المشاعر بكل صراحة ووضوح بمثل (أحب، أكره، لا أوئد......)

- لا تتجاوز فترة التعبير عن المشاعر . ثانية

د - الحلديث الفمال أثنائ الاجتماع

- عرض إيجابيات وفوائد الموضوع

- استخدام لغة الجسد (إشارات، إيماءات، نغمة الصوت)

- الالتزام بالموضوع وعدم الخروج عنه -

- الاستدلال بتجارب مماثلة ناجحة لأشخاص أو مدارس أو دول

•_ـقدل موضوع الاجتماع

- عرض وجهات النظر السلبية بكل حرية دون قيود.

- انتقاد الموضوع وليس الأثخاص.

- - احترام الرأي الآخر المعارض.

وـ_إثراء موضوع الاجتماع فكريًا

- أن تكون هذه المقترحات واقعية قابلة للتطبيق

- عدم الإسهاب في طرح المقترحات منعًا للتشتت عند الاختيار بينها.

ز_ضبط النظام أثناء الاجتماع

- إدارة الاجتماع وتجنب هدره بما لا يثري موضوع الاجتماع. - ت تخيم الحوار وعدم المقاطعة.

- العدل في توزيع المشاركة على جميع الأعضاء. 


$$
\begin{aligned}
& \text { ح__ حسن الختام } \\
& \text { - - تلخيص ما دار في الاجتماع. } \\
& \text { - - إعلان القرارات وتوزيع خطط ومسؤوليات التنفيذ. }
\end{aligned}
$$

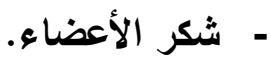

$$
\begin{aligned}
& \text { - أما مهارات إدارة الاجتماع لأعضاء الاجتماع فهي كالتالي: } \\
& \text { أ_ الموضوعية في الطرح }
\end{aligned}
$$

- عرض الحقائق والمعلومات المتعلقة بموضوع الاجتماع كما هي دون تفسير أو تحليل. - عرض الحقائق والمعلومات بعيدًا عن الآراء والعواطف الثخصية. ب_التعبير عن المشاعر - التعبير عن المشاعر بكل صراحة ووضوح بمثل (أحب، أكره ، لا أوئل.....)

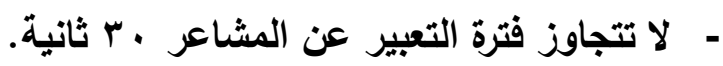
ج_الحليث الفعال أثناء الاجتماع - عرض إيجابيات وفوائد الموضوع.

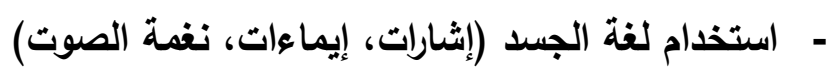
- الالتزام بالموضوع وعدم الخروج عنه. -

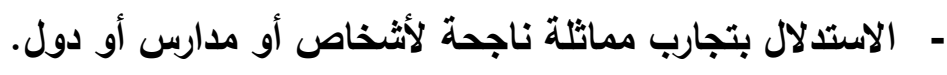
د__نقد موضوع الاجتماع - عرض وجهات النظر السلبية بكل حرية دون قيود. - - انتقاد الموضوع وليس الأشخاص.

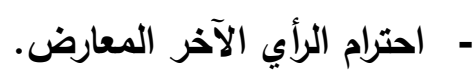
هـ_ إثراء موضوع الاجتماع فكريًا. - أن تكون هذه المقترحات واقعية قابلة للتطبيق. - عدم الإسهاب في طرح المقترحات منعًا للتشتت عند الاختيار بينها. النتيجة الثانية : الإجابة عن سوأل الدراسة الفرعي الثاني: ما خطوات إستراتيجية التدريس القائمة على برنامج قبعات التفكير الست أثناء تدريس مقرر اللغة العربية ؟ - سبق توضيحها في عند عرض منهج البحث وإجراءات الدراسة وهي مفصلة بملحق 1. 
النتيجة الثالثة : الإجابة عن سؤال البحث الرئيس - ما أثر إستراتيجية التثريس القائمة على برنامج قبعات التفكير الست لتنمية مهارة إدارة الاجتماع لاى عينة من طالبات جامعة الحدود الثمالية عند دراسة مقرر اللغة العربية؟ الثابه

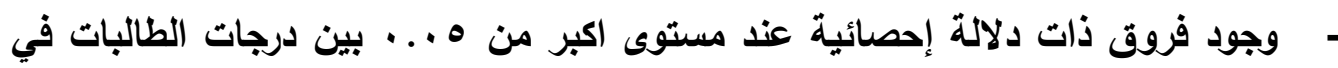
بطاقة الملاحظة لمهارات إدارة الاجتماع ككل في المجموعتين التجريبية والضابطة لصالح

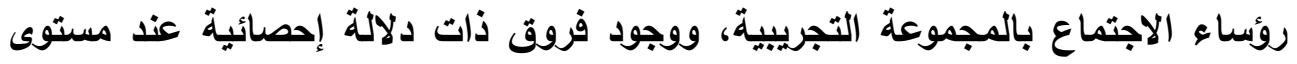
اقل من ال... بين درجات الطالبات لمهارات إدارة الاجتماع ككل في المجموعتين التجريبية والضابطة لصالح أعضاء الاجتماع بالمجموعة التجريبية، مما يدل على أثر الثرات

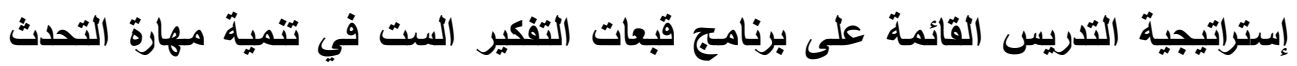
(إدارة الاجتماع) عذد تعليم اللغة العربية لاى طالبات المرحلة الجامعية بجامعة الحدود

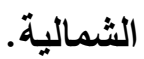

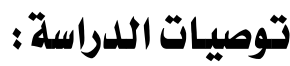

وفق ما أسفرت عنه النتائج توصي الباحثة بما يلي:

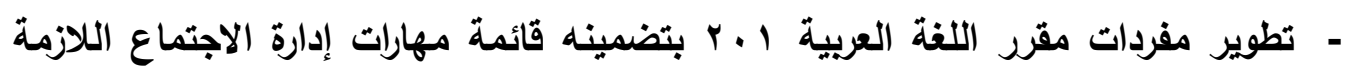
لكل من رئيس وأعضاء الاجتماع ووصف الأنثطة التريسية اللازمة لتمكين الطالبات

منها.

- استخدام إستراتيجية التريس القائمة على برنامج قبعات التفكير الست عند تدريب الطالبات على مهارة التحدث أثناء تدريسهن جميع مقرات اللغة العربية. - إعطاء مهارة التحدث الوقت الكافي لتعليمها ضمن الخطة الدراسية وتعزيز مهارات تنمية

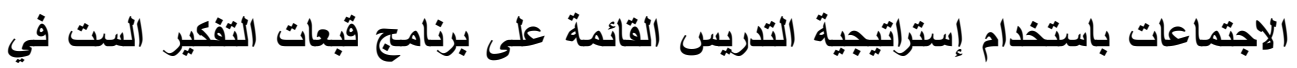

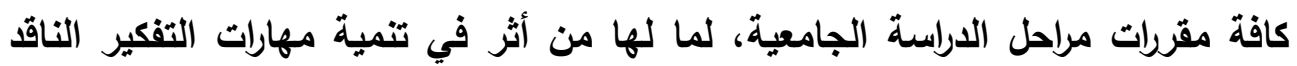
والإبداعي.

- الاستفادة من الإستراتيجية القائمة على برنامج قبعات التفكير الست عند تدريس المواد الدراسية الأخرى مثل: قواعد اللغة العربية والإعراب وتحليل النص الأدبي في مقر الأدب

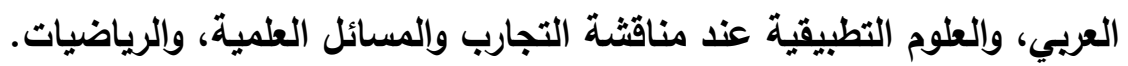


- استخدام أداة تقويم مهارات إدارة الاجتماع لاى الطالبات عند تلريسهن مهارة التحدث في جميع المقررات الجامعية لتعزيز تحقيق التواصل الفعال بين الطالبة والمجتمع الجامعي .

مقترحات الدراسة

بعد عرض توصيات الاراسة تقترح الباحثة إجراء دراسات ويحوث تتناول مايلي: - الكثف عن أثر وفاعلية برامج وإستراتيجيات حديثة في تنمية مهارة التحدث مثل: برنامج

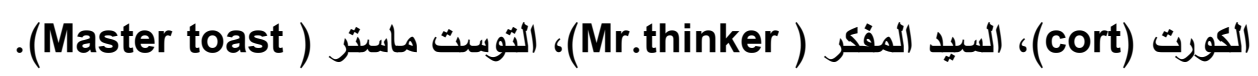
- دراسة فاعلية إستراتيجيات تدريس ويرامج تدريبية جديدة لتنمية مهارات أخرى للتحدث (Mrt) مثل: إستراتيجية السرد القصصي، وإستراتيجية التخيل البصري . - الكثف عن أثر إستراتيجية التدريس القائمة على برنامج قبعات التفكير في تتمية التفكير

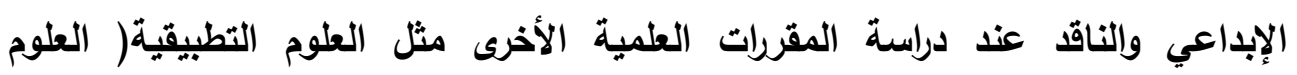
والرياضيات والإحصاء ، والكيمياء والأحياء ...) والعلوم الإنسانية (التاريخ والجغرافيا والعلوم الشرعية واللغة العربية ....). 


\section{المراجع}

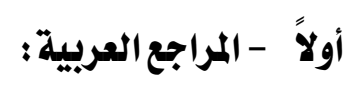

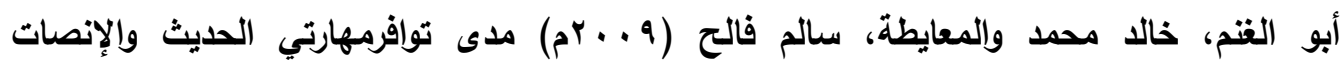

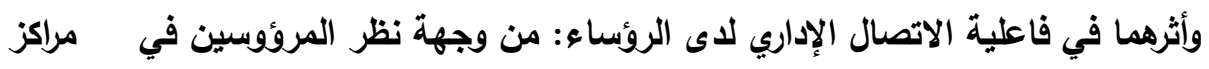

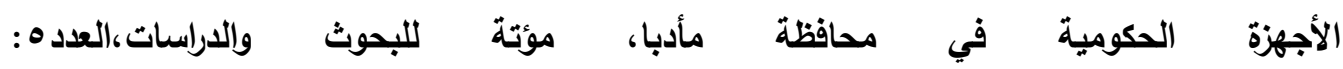
$r \wedge r-r \leqslant 9$

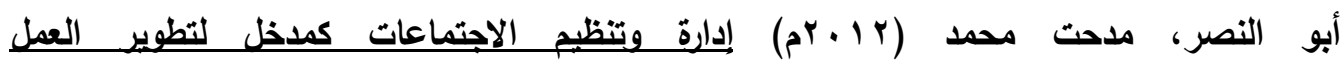

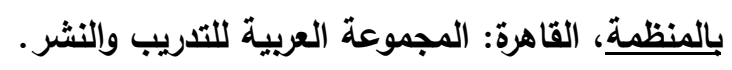

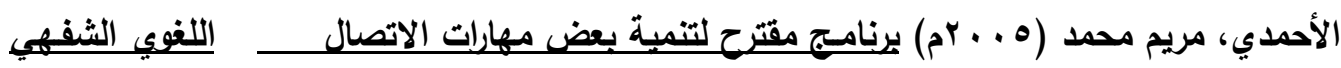

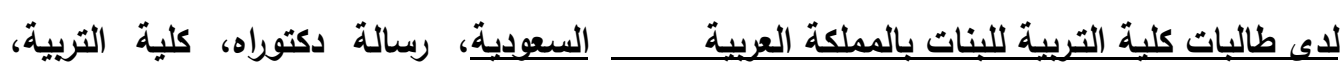

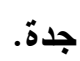

بلدوي، أحمد زكي ( د ت ) معجم مصطلحات العلوم الاجتماعية، بيروت: عالم الكتب.

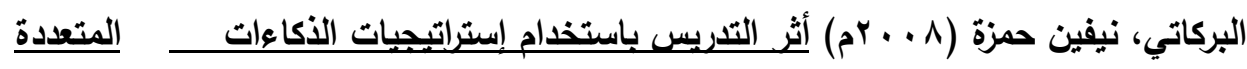

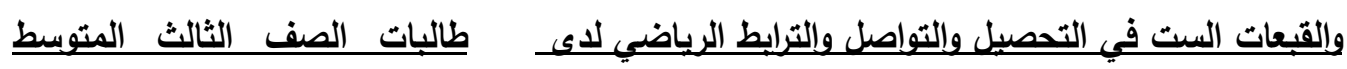
بمدينة مكة المكرمة، رسالة دكتوراة، جامعة أم القرى، مكة المكرمة.

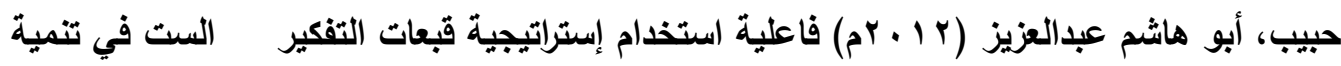

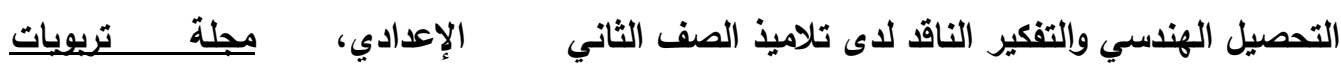
الرياضيات، العدد ؛: lV

حجاب، محمد ( r . . rم) مهارات الاتصال للإعلاميين والتربيين والدعاة، ط ع، القاهرة: دار

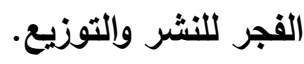

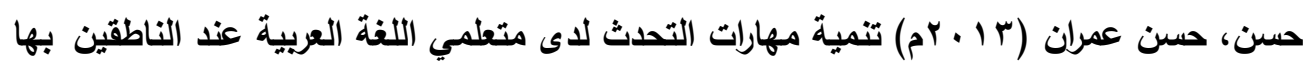

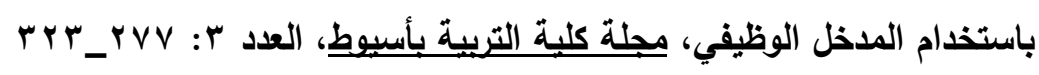
الحسون، جاسم محمود و الخليفة، حسن جعفر ( 1994م) طرق تعليم اللغة العربية في التطليم العام، البيضاء: جامعة عمر المختار. 


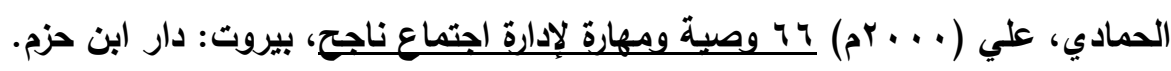
الخزرجي، مثنى إبراهيم (11 +rم) أثثر إستراتيجية القبعات الست في التحصيل لاى طلاب المرحلة المتوسطة في مادة التاريخ، رسالة ماجستير، جامعة ديالى، بعقوية.

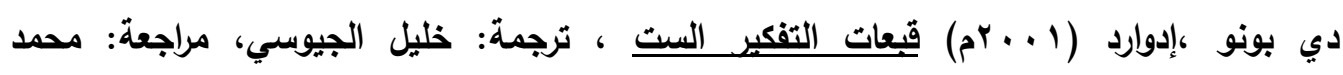
عبدالله البيلي، أبوظبي: المجمع الثقافي.

الرازي، محمد بن أبي بكر (r ا •rم) مختار الصحاح، بيروت: دار المعرفة.

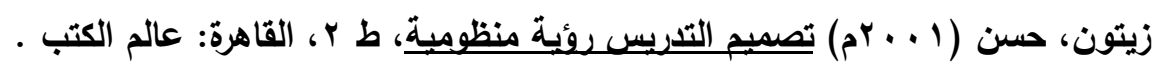

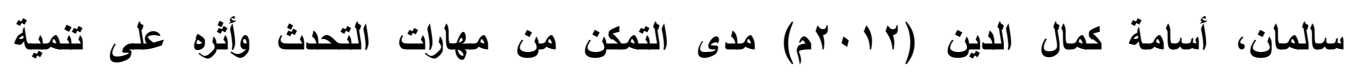

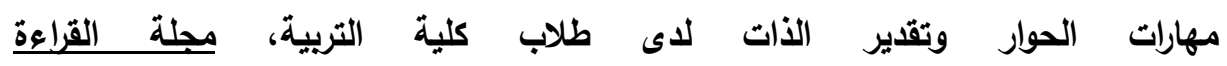

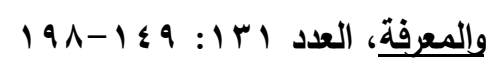

السيد، محمود (د ـ ت) في قضابيا اللغة التريوية، الكويت: وكالة المطبوعات .

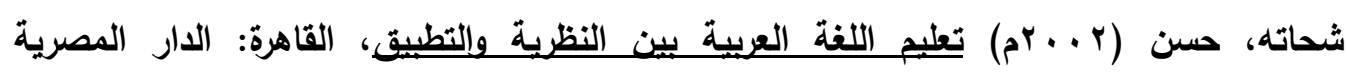
اللبنانية .

طعيمه، رشدي أحمد (991 ام) الأسس العامة لمناهج تعليم اللغة العربية إعدادها_تطويرها و و

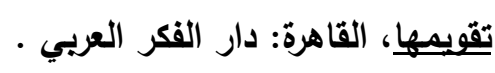

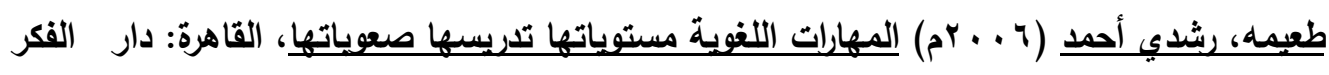

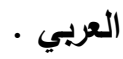

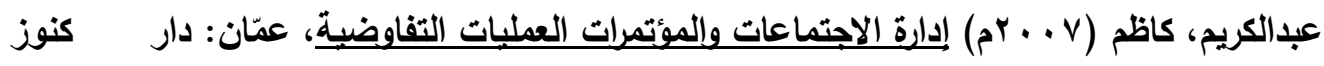
المعرفة .

العتيبي، مها محمد (q. . Pم) أثر التدريس بإستراتيجية قبعات التفكير الست في التحصيل

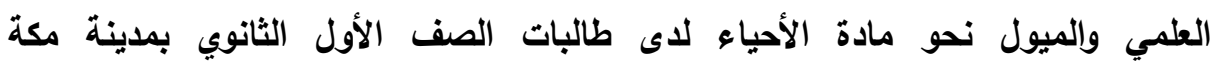

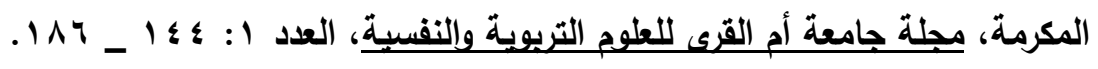

العثيمين، فهـ بن سعود بن عبدالعزيز (ra 9 (1) الاتصالات الإدارية " ماهيتها، ما أهميتها، أساليبيها " الرياض: مطابع شركة الصفحات الذهبية المحدودة . 


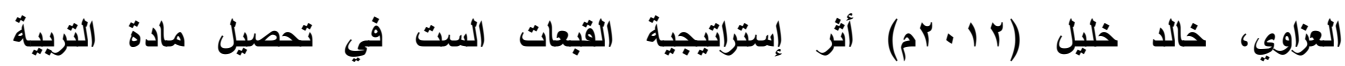

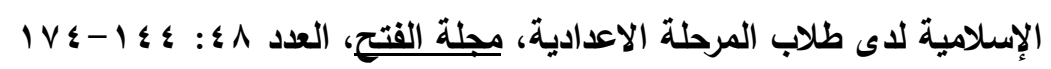

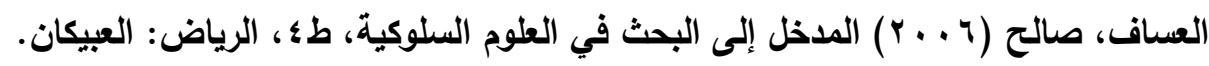

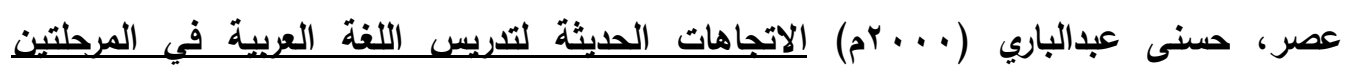

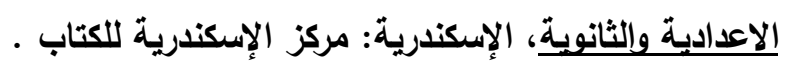

عصفور، إيمان حسين محمد (· • (rم) استخدام طريقة قبعات التفكير الست في تجنب أخطاء

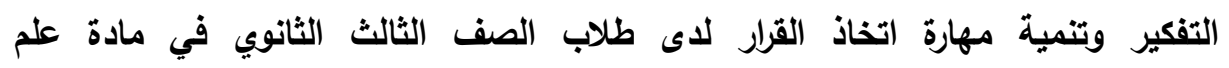

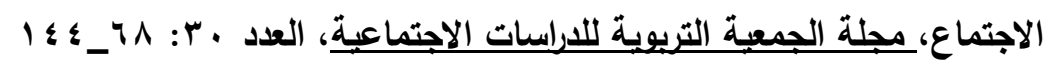

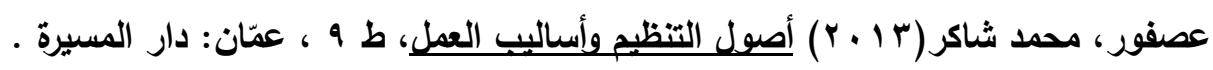

عليان، أحمد فؤاد (999 (م) المهارات اللفوية ماهيتها وطرائق تنميتها، طץ، الرياض: دار المسلم للنشر والتوزيع.

علي، كمال زعفر (11 +rام) القراعة والمحادثة في ضوع منهج تكاملي، طץ، الدمام: مكتبة المتنبي.

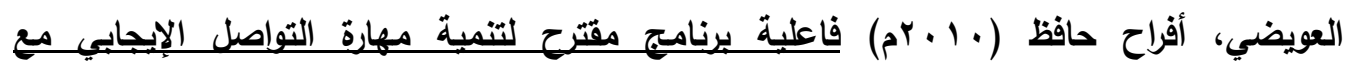

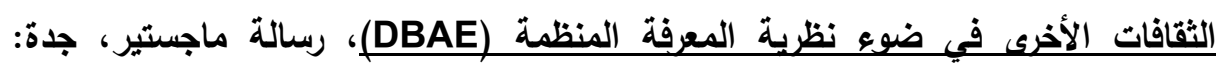
جامعة الملك عبدالعزيز.

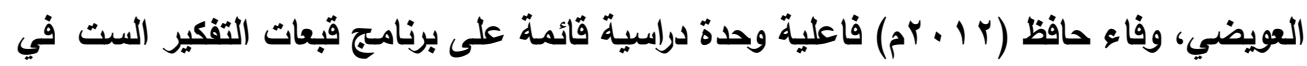

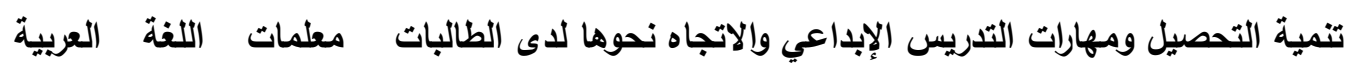

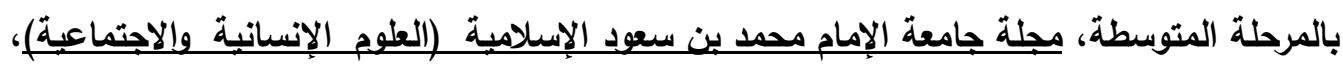

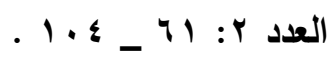

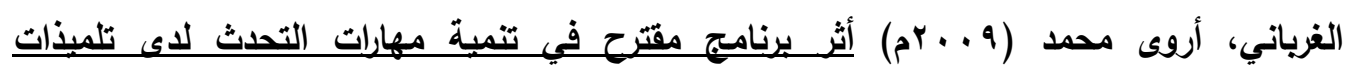

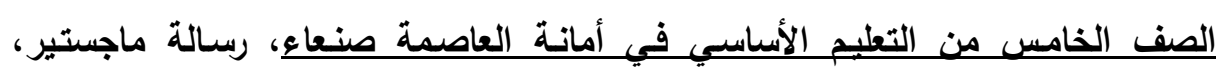

جامعة صنعاء، صنعاء. 


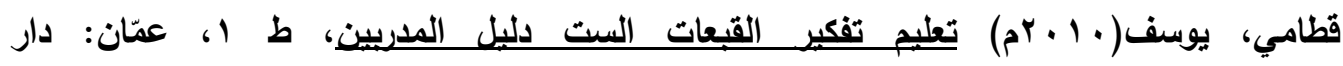
المسيرة.

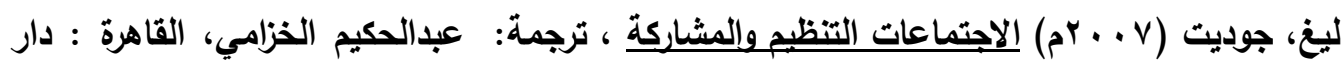

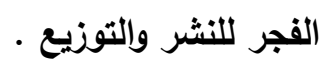

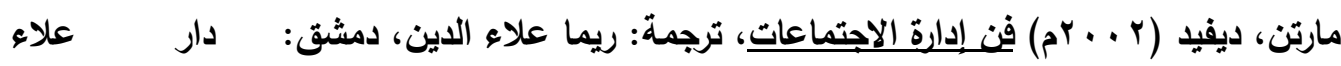
الدين.

ماكولاف، وليم (991) فن التحاور، ترجمة: أحمد خيري، القاهرة: المطبعة الخيرية الحديثة.

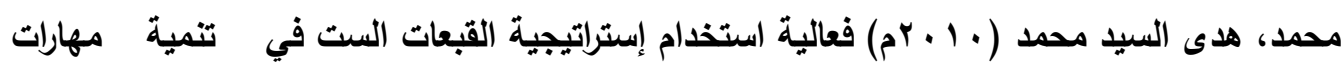

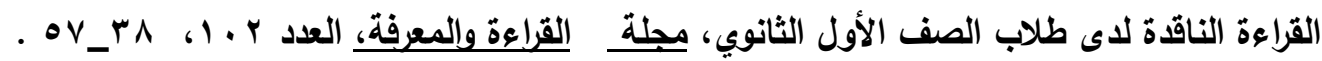

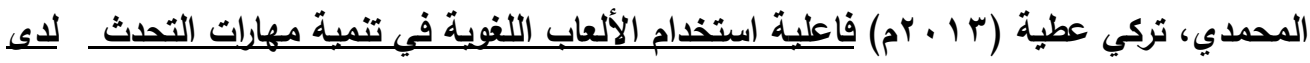
تلاميذ الصف الأول الابتائي، رسالة ماجستير، جامعة أم القرى، مكة المكرمة. مدكور، علي أحمد (r . rم) تدريس فنون اللغة العربية، القاهرة: دار الفكر العربي.

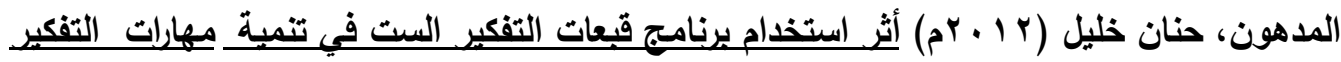

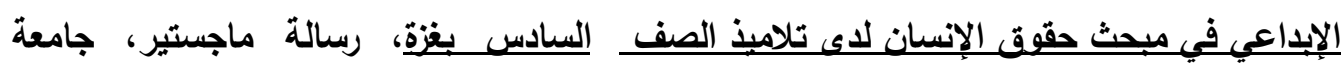

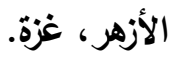

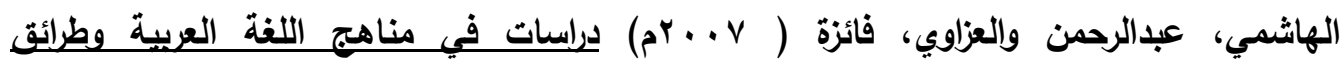
تذريسيها، عمّان: مؤسسة الوّرلق للنشر والتوزيع.

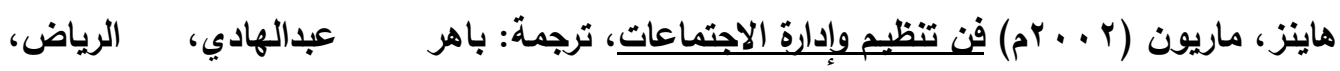
دار المعرفة للتنمية البشرية.

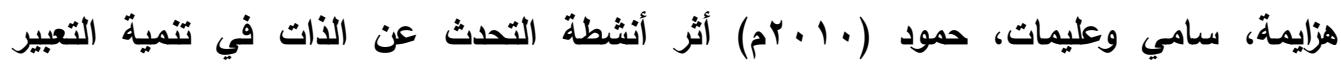

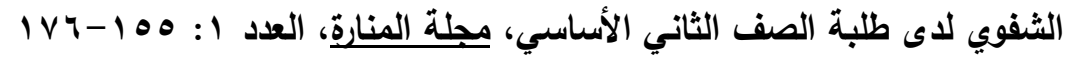


Curran Kerry(2003) Six Thinking Hats in meetings of the classroom, the primary educator, Issue 3: 240-276

Debono, Edward (2007), Thinking ahead the Publication for Learning and Development, Journal , 19 _ 21

Fateh , Muhammad Ali (2007), Six Thinking Hats effect on student achievement in the teaching of subjects related to sustainable development in geography, phd Thesis , University of Siirt, Siirt.

Jahed, Hakeem , Godit (2012) The effect of using the Six Thinking Hats program in writing skill development among sixth graders primary Turkey, journal of Academic Studies, Volume 14, Issue 55: 122- 147 